\title{
CLINICAL AND LABORATORY EVIDENCE LINKING ALLERGY AND ACUTE OR CHRONIC RHINOSINUSITIS IN CHILDREN.
}

\author{
Eugenio DE CORSO ${ }^{1}$, DANIELA LUCIDI ${ }^{2}$, ELENA CANTONE ${ }^{3}$, GIANCARLO \\ OTTAVIANO $^{4}$, TIZIANA DI CESARE ${ }^{1}$, VERONICA SECCIA ${ }^{5}$, GAETANO \\ PALUDETTI $^{1}$, and JACOPO GALLI ${ }^{1}$ \\ ${ }^{1}$ University Hospital Agostino Gemelli \\ ${ }^{2}$ University Hospital Modena \\ ${ }^{3}$ Federico II University Hospital \\ ${ }^{4}$ Università degli Studi di Padova \\ ${ }^{5}$ Azienda Ospedaliero Universitaria Pisana
}

June 22, 2020

\begin{abstract}
Background: allergic rhinitis is a common childhood disease in industrialized countries that is responsible for a major impact on quality of life and health care resources. The objective of this review was to provide a systemic review of experimental and clinical evidence linking allergy to rhinosinusitis in children including common cold. Furthermore, we questioned if antiallergy treatment may prevent the occurrence of rhinosinusitis or improve outcomes of its specific management. Methods: This systematic review was conducted in accordance with the Preferred Reporting Items for Systematic Review and Meta-Analysis (PRISMA) process to identify experimental and clinical articles about allergy and acute or chronic rhinosinusitis in children published since January 2000. The research was performed in April 2020 including only English-language peer-reviewed papers. Our search yielded 7103 that were finally screened. This resulted in 30 publications of which the full texts were assessed and included in a qualitative analysis per different phenotypes of rhinosinusitis. Results: The evidence suggests that allergy may lead to overall impairment of mechanical and immunological defense function of the nasal mucosa against viruses and that antiallergy treatment may significantly decrease the number and severity of upper respiratory tract infections including common colds in children. It was not possible to perform the analysis for allergy and post viral acute rhinosinusitis, bacterial acute rhinosinusitis and recurrent acute rhinosinusitis because of paucity and heterogeneity of data. We found interesting data linking allergy to chronic rhinosinusitis: although there is no definitive proof of causation studies lead to suppose that anti-allergy treatment may improve outcomes of specific CRS treatments. Conclusion: We summarized conclusions in a practical algorithm taking into account different phenotypes of rhinosinusitis in order to elucidate when prompt and accurate diagnosis of allergy is recommended. We lastly focused attention on the needs for future research.
\end{abstract}

\section{INTRODUCTION.}

Allergic rhinitis (AR) in children has a significant impact on global quality of life, including school performance, sleep disorders, and emotional health ${ }^{(2)}$. Furthermore, over the years many authors tried to correlate allergy with comorbidities and in particular to the onset of rhinosinusitis including common cold, even though conflicting results are frequently reached.

$\mathrm{AR}$ is a nasal mucosa inflammatory condition caused by environmental allergens interacting with immunoglobulin (Ig) E in sensitized subjects. Repeated exposure may lead to long-term changes in systemic 
and local inflammation, including up-regulation of nasal eosinophils and allergen-specific IgE, increased levels of adhesion molecules in airway mucosa and enhanced systemic response to allergen challenge ${ }^{(4)}$. Consequently, it is not surprising that AR has been historically associated with comorbid upper airway diseases ${ }^{(5)}$. Herein, we review clinical and laboratory evidence, linking allergy to rhinosinusitis in children. We aimed to investigate allergy not only as etiologic, but also as a worsening factor; in fact, poorly controlled AR might contribute to exacerbations and as such its adequate treatment might improve outcomes ${ }^{(6)}$.

\section{Material and methods.}

\section{Search strategy}

This systematic review was conducted in accordance with the Preferred Reporting Items for Systematic Review and Meta-Analysis (PRISMA) process to identify published experimental and clinical articles about allergy and rhinosinusitis including common cold in children. Manuscript were screened primarily by Ovid Medline and EMBASE and from other sources (Pubmed Central, Cochrane review, Web of Science, and Google Scholar) and published from January 2000 to April 2020. Only 3 articles before this date were included because considered particularly relevant for this systematic review. Literature searches were performed in April 2020.

We performed two different searches using MeSH-terms. One group of authors focused on experimental studies matching the term as follow: ((Rhinovirus) OR (coronavirus) OR (epithelial barrier) OR (epithelial cells) OR (barrier function) OR (nasal epithelial cells) OR (viral infections)) AND ((Allergy) OR (Allergic rhinitis) OR (Atopy) OR (Atopic) OR (Allergic Children) OR (Non allergic children) OR (immunoglobulin E)) AND ((children) OR (childhood) OR (pediatric)). The second group of authors focused on clinical studies, matching the term as follow: ((respiratory infections) OR (acute rhinosinusitis) OR (Chronic rhinosinusitis) OR (Sinusitis) OR (Rhinosinusitis) OR (Recurrent sinusitis) OR (endoscopic sinus surgery) OR (URTI) OR (Upper Recurrent Respiratory Infection)) AND ((Allergy) OR (Allergic rhinitis) OR (Atopy) OR (Atopic) OR (Allergic Children) OR (Non allergic children) OR (immunoglobulin E) OR (immunotherapy) OR (antihistamine)) AND ((children) OR (childhood) OR (pediatric)).

Study selection.

In the first screening authors read the title and abstract of articles selecting those being as inclusive as possible. The abstracts were screened independently by reviewers of the two groups. Any disagreements were resolved by consensus. Inclusion and exclusion criteria were established before the selection of relevant studies. The inclusion criteria were primary research (including descriptive studies, observational studies, randomized trials, and basic science articles), published after January 2000, addressing allergy and rhinosinusitis in children including common cold. Furthermore, we questioned if anti-allergy treatment may prevent the occurrence of rhinosinusitis or improve its specific management.

We excluded secondary research studies (e.g., review articles or systematic review), case studies, newspaper article, lecture, letter, comment, personal narrative, consensus conference, editorial. Only articles with full text available were included. Additional studies were manually identified from the reference lists of retrieved literature. We excluded all the article that did not meet the inclusion criteria or deal directly with the issue investigated. We made exceptions for experimental models including studies on cultured epithelial cells obtained from adults, which are obviously more frequent than from children. Based on our review was not possible differentiate between atopy or sanitization and allergy. We included only English-language peer-reviewed papers.

\section{RESULTS}

The details of the systematic search performed are shown in Fig. 1. In total, our search yielded 9870 after duplicates removal. We excluded 2767 due to time of publication and type of article, then 7103 were finally screened. This resulted in 30 publications of which the full texts were assessed and included in a qualitative analysis. We summarized in tables the included studies per each phenotype classifying evidence using GRADE methodology. No studies were included in a quantitative synthesis (meta-analysis). 


\section{Allergy and acute rhinosinusitis in children.}

According to the EPOS2020 guidelines $^{(7)}$, acute rhinosinusitis in children (ARS) is defined as a sudden onset of two or more of the following symptoms: nasal blockage/obstruction/congestion, discoloured nasal discharge and cough (daytime and night-time) for $<12$ weeks. ARS in children can theoretically be divided into viral acute rhinosinusitis (i.e. common cold), post-viral rhinosinusitis, acute bacterial rhinosinusitis (ABRS). Acute viral rhinosinusitis has usually a duration of symptoms of $<10$ days. Post-viral one is defined if symptoms increase after five days, or are persistent for more than 10 days, with less than 12 weeks duration; only a small subgroup of these are of bacterial origin. Discolored mucous, severe pain, fever $>38$, "double sickening" lead to the suspicious of bacterial supra infection. Recurrent ARS(RARS) is defined as [?]4 episodes of rhinosinusitis per year with symptom-free intervals.

\section{Allergy and acute viral rhinosinusitis in children (i.e common cold) including viral upper respiratory tract infections (URTIs).}

Viral acute rhinosinusitis (i.e common cold) may be induced in children by a wide variety of viruses, such rhinoviruses (RV) and coronaviruses (CorV), as well as respiratory syncytial virus (RSV), parainfluenza viruses and adenoviruses. The common cold is the most frequent upper respiratory tract infection (URTI), which are the most commonly treated acute problems in primary pediatric care ${ }^{(8)}$. URTI are caused mainly by viruses and may involve not only nose and sinuses but also pharynx, larynx, and large airways. Clinical expression of URTIs is variable and it is influenced by the nature of the infecting virus, by the age and by physiological state and immunological experience of the host. Sino nasal clinical features of common cold or URTI commonly overlap and are characterized by self-limiting irritation of the upper airways with associated cough with no proof of pneumonia ${ }^{(9)}$. Based on our review of the literature we observed that authors for research purpose include common colds in URTI; for this reason, we included both papers about allergy and common cold or URTI.

\subsubsection{Laboratory evidence linking allergy to increased risk of epithelial cells viral infection.}

All experimental studies included in the qualitative analyses suggest that allergy may increase the risk of viral infections of upper airways epithelial cells consequent to Th2-polarization (Table I). The mechanisms involved may be related to enhanced adherence of pathogens to inflamed respiratory epithelium, increased mucosal permeability, altered immune response to certain viral pathogens, and excessive mucus production and modifications of mucus consistency as pabulum for microbe overgrowth ${ }^{(10)}$.

Allergy may induce inflammation of the nasal mucosa leading toimpairment of epithelial barrier function and secondary deficiency of early local immune reaction. Several studies demonstrated, in fact, that the upper airway epithelium represents not only a mechanical wall against pathogens by muco-ciliary clearance, but also an immunological barrier modulating the innate immune response through cytokine production ${ }^{(11)}$.

Interestingly, authors ${ }^{(12,13)}$ demonstrated impairment of the overall mechanical function of the epithelium and, in particular, decreased expression of tight-junction proteins occludin and zonula occludens- 1 in cultured epithelial nasal cells from allergic patients. Steelant et al. ${ }^{(14)}$ demonstrated that nasal secretions from allergic subjects rapidly decrease the trans-tissue resistance of epithelial cell cultures in vitro. They also showed that anti-IL-4 treatment in mice prevented epithelial barrier disruption. Finally, several authors have demonstrated $^{(15,16)}$ that allergy may expedite viral overcome of mechanical barriers because TH-2 polarized cytokines such as IL-4, IL-5, and IL-13 can upregulate endothelial and epithelial expression of adhesion molecules like intercellular adhesion molecule-1 (ICAM-1), which is the receptor for $90 \%$ of rhinoviruses.

On the other hand, several authors demonstrated that allergy may modify the immunological functions of the epithelia. Many studies showed the deficiency of the innate immune response in allergic mucosa of upper and lower respiratory epithelia cells. Furthermore, it has been demonstrated in the lab that interferon production may be defective in allergic patients. Interferons are crucial for induction of apoptosis in virusinfected host cells because they prevent establishment of viral replication and promote phagocytosis of infected cells ${ }^{(17,18,19)}$. Accordingly, in 2015 Teach et al. ${ }^{(20)}$ found that peripheral blood mononuclear cells 
cultured from a subset of atopic children treated with anti-IgE improved INF- $\alpha$ production after incubation with rhinovirus.

\subsubsection{Clinical evidence linking allergy to risk of viral upper respiratory infection.}

From a clinical point of view, the results are more controversial than those from the laboratory. Studies in the literature comparing the incidence of upper respiratory infections between allergic and non-allergic subjects are relatively few in number (see 4 articles included in the qualitative analyses in table II).

In two manuscript has been demonstrated that atopic/allergic patients had increased susceptibility to upper respiratory infections. In 2006, in a large cross-sectional survey Karevold et al. ${ }^{(21)}$ demonstrated that atopy increases the risk of developing upper and lower respiratory tract infections in children. In particular, atopy was the strongest risk factor, such as in the home environment (dampness). Accordingly, Ciprandi et al. ${ }^{(22)}$ observed that allergic children have a significantly higher number of upper respiratory infections, more serious in duration and severity, compared with non-allergic ones.

Other authors disagree: Kværner et al. ${ }^{(23)}$ reported that correlation between upper respiratory infection and atopic diseases from a population-based sample of 7992 Norwegian twins was weak, even though results were inconclusive. Sütçü et al. ${ }^{(24)}$ confirmed that the number of episodes per year was not significantly different between atopic and healthy children, even though atopic ones had longer episodes of recurrent URTI compared to controls.

Interestingly all clinical studies included in the qualitative analyses about therapy (Table II) supported the hypothesis that anti-allergy specific or non-specific treatments may prevent viral infections of the upper airways. Antihistamine therapy can act by reducing the expression of adhesion viral receptors to modulate the production of TH-2 related interleukins ${ }^{(22)}$. Authors ${ }^{(16,25)}$ demonstrated that children treated with cetirizine had a significant reduction in ICAM-I expression on epithelial cells, thus preventing possible relapse of rhinovirus infections and diminishing both the number and severity of recurrent respiratory infections in children. Barberi et al. ${ }^{(26,27)}$ demonstrated that children treated with sublingual immunotherapy (SLIT) had significantly fewer respiratory infections (RI) than symptomatically treated children. In addition, SLITtreated children had less fever episodes per year and took fewer medications vs. symptomatically treated children.

\subsection{Allergy and post-viral acute rhinosinusitis and acute bacterial rhinosinusitis (ABRS) in children.}

In the articles reviewed we did not find manuscript in which authors distinguished between post viral ARS and ABRS. Authors focused the attention in the particular on the risks of bacterial superinfection. Recent evidence suggests in fact that damage or disruption of mucociliary function due to viral infection is probably a major cause of super- or secondary bacterial infection. Allergy is a condition that potentially can exacerbate an inflammatory sino-nasal response, although very limited data are available to confirm this hypothesis. ${ }^{(28)}$ Based on paucity and heterogeneity of the studies it was not possible to perform a qualitative analysis linking allergy to ABRS or to post viral $\mathrm{ARS}^{(7)}$ for this reason we report by a narrative description available data.

Lin et al. ${ }^{(29)}$ demonstrated that the prevalence of colonization by methicillin-resistant S. aureus was higher in atopic children than healthy ones and that atopic children were more likely to develop ARS than nonatopic ones. Interestingly, other authors ${ }^{(30)}$ observed that AR was highly prevalent in orbital ARS complications in children and, specifically, it was found in $64.3 \%$ of children with pre-septal cellulitis, in $25 \%$ with periostitis, and in $76.5 \%$ with subperiosteal abscess. Furthermore, the prevalence of AR was significantly higher in patients presenting in pollen season from February to August than in patients presenting between September and January. The authors suggested that allergy may be a cofactor in the pathogenesis of orbital complication of ARS. In addition, Alho et al. ${ }^{(31)}$ observed that subjects with allergic IgE-mediated rhinitis had more severe paranasal sinus changes in CT scans than non-allergic subjects during viral colds. The authors suggested that these changes were signs of more severely impaired sinus function, increasing the risk of bacterial sinusitis. 
Shi-Wei Lin et al. ${ }^{(32)}$ recently evaluated the risk of incident acute rhinosinusitis among children with allergic rhinitis, using a nationwide, population-based health claims research database and including a large number of patients. The authors observed that the risk of acute rhinosinusitis was significantly higher in pediatric patients with allergic rhinitis compared to those without the condition (adjusted hazard ratio $=3.03,95 \%$ confidence interval $=2.89-3.18$ ). Caution is advised when interpreting the findings of the authors due to limitations of the study: retrospective design, diagnosis of ARS based on clinical history (authors could not confirm bacterial etiology of sinusitis).

On the other hand, Leo et al. ${ }^{(33)}$ demonstrated that children with grass pollen induced rhinitis during exposure to pollen had an incidence of endoscopically confirmed ARS comparable to non-allergic children; they consequently suggested that AR was a negligible risk factor for ARS and that the most common risk factor was instead a previous acute viral infection. Accordingly, EPOS 2020 concluded that there appears to be small evidence to support the presence of AR as a risk factor for developing ARS in children, recognizing a central role for previous viral infection.

\subsection{Allergy and recurrent acute rhinosinusitis (RARS) in children.}

We found very limited and heterogeneous data linking allergy to RARS and it was not possible to perform a qualitative analysis. Choi et al. ${ }^{(34)}$ evaluated the predisposing factors that may be associated with chronic and recurrent RS examining 296 patients with RS younger than 13 years of age. The prevalence of allergic rhinitis, atopy, and asthma were significantly higher in patients with chronic and recurrent RS than those with acute and subacute RS. Veskitkul et al. ${ }^{(35)}$ evaluated the clinical characteristics and predisposing factors of RARS in children as well as the preventive therapy. The authors suggested that allergic rhinitis may be considered a predisposing factor because it was detected in $35.1 \%$ of cases, concluding that children with RARS should be always evaluated for the presence of underlying predisposing conditions including allergic disease. Nevertheless, no comparison with a control group was performed and for this reason data are not definitely supporting a link between allergy and RARS.

\section{Allergy and Chronic Rhinosinusitis (CRS) in Children.}

Chronic rhinosinusitis (with or without nasal polyps) in children is defined as: presence of two or more symptoms, one of which should be either nasal blockage/obstruction/congestion or nasal discharge (anterior/posterior nasal drip) with or without facial pain/pressure and/or cough for [?]12 weeks associated to pathognomonic endoscopic signs or CT changes ${ }^{(7)}$. The prevalence of CRS in children is lower than in adults (2-4\%), nevertheless, the negative impact on quality of life seems to be similar to that observed in adults. Studies on CRS in children are less common and it is more difficult to investigate the relationship with allergy ${ }^{(7)}$. Several factors contribute to complicate the analyses including incomplete evaluation (nasal endoscopy and/or imaging are rarely performed in many children) and the difficulty to differentiate CRS from adenoid hypertrophy, adenoiditis, and (allergic) rhinitis. In fact, nasal blockage may occur in AR children, due to edematous mucosa, neurogenic and vascular responses, over-production of secretions, and impaired muco-ciliary clearance leading to congestion of the ostia and symptoms simulating rhinosinusitis. On the other hand, the blockage leads to stagnant debris and acidotic environment that might stimulate bacteria overgrowth $^{(36,37)}$.

Histopathological analysis ${ }^{(38,39)}$ demonstrated that pediatric CRS is quite different from the adult form, showing greater inflammatory cellularity, higher density of submucosal lymphocytes, less eosinophilic inflammation, basement membrane thickening, and mucous gland hyperplasia, suggesting a different pathway compared to the adult CRS pattern, which is predominantly characterized by a Th2-oriented response with polypoid changes. The presence of nasal polyps in a pediatric patient should suggest the hypothesis of cystic fibrosis that has not been included in this paper. More specifically, some evidence supports the hypothesis that CRS in children over the age of 13 seems to be based more on eosinophilic inflammation, while under this age CRS seems to be based more on neutrophilic inflammation, thus justifying the lower prevalence of nasal polyps in children than in adult ${ }^{(38,39)}$.

Several manuscripts support the hypothesis that AR and CRS could be different faces of the same disease. 
AR, in fact, is typically characterized by a Th2 immune response involving IL-4, IL-5 and IL-13 which drives IgE production and recruitment of eosinophil granulocytes. It has been suggested ${ }^{(40-44)}$ that eosinophils, by generating potent toxic agents (cationic proteins, oxygen-free radicals, and proinflammatory cytokines), may play a major role in initiating and perpetuating inflammation of sino-nasal mucosa in patients with AR.

2.1.1 Evidence from the lab linking allergic inflammation to increased risk of chronic rhinosinusitis in children.

All studies included in a qualitative analysis support a specific link between CRS and AR in children (Table III). Chawes ${ }^{(45)}$ studied nasal eosinophilia and nasal airway patency (assessed by acoustic rhinometry) in children with AR, non-allergic rhinitis and healthy controls. Nasal eosinophilia and irreversible nasal airway obstruction were significantly associated with AR, whilst there was no such association with non-allergic rhinitis. The authors suggested that chronic inflammation and structural remodeling of the sino-nasal mucosa may occur in allergic children even at 6 years of age.

Some authors suggested that allergic sino-nasal inflammation may support bacterial infection. Blair et al. ${ }^{(46)}$ in an animal model showed that allergic inflammatory reaction may obstruct sinus drainage encouraging bacterial infection into the maxillary sinus. Shin et al. ${ }^{(47)}$ demonstrated that total IgE, total eosinophil count, and serum eosinophil cationic protein levels were significantly higher in CRS children whose symptoms and radiologic abnormalities did not resolve after 12 weeks despite appropriate antibiotic therapy (non-responder) compared with responders and healthy controls. Moreover, AR in children may affect the efficiency of mucociliary clearance, which is one of the most important protective functions of the respiratory epithelium. Deterioration of muco-ciliary system appears to be related to more severe rhinitis with a higher intensity of local nasal inflammation, reflected in nasal smear eosinophilia ${ }^{(48)}$.

Brożek-Madry and co-workers ${ }^{(49)}$ evaluated the relation between bacterial strains and cytological examination of nasal mucosa in children with CRS; they found that the most common strains of bacteria observed in CRS (Hemophilus influenzae, Moraxella catarrhalis, and Staphylococcus aureus) were associated with a higher prevalence of atopy and percentage of eosinophils in cytology. It must be noted that S. aureus enterotoxins are able to induce increased severity of the disease, amplifying eosinophilic inflammation in atopic patients ${ }^{(50)}$.

\section{Clinical evidence linking allergic inflammation to increased risk of chronic rhinosinusitis.}

The association between allergy and CRS in adults has been discussed for years and a strong association has been observed with particular subtypes of CRS with nasal polyps (wNP), such as central compartment atopic disease and allergic fungal rhinosinusitis ${ }^{(51,52)}$. Manuscripts on pediatric CRS are less common predominantly because of ethical issues regarding administration of X-rays in the pediatric population. The publications included in the qualitative analyses are summarized in Table IV. Conclusions of the studies included in the qualitative analyses were not unanimously linking allergy to chronic rhinosinusitis.

Several manuscripts seem to support a positive clinical association between AR and CRS, describing a prevalence varying between $27 \%$ and $59 \%$ of patients ${ }^{(53,54,55)}$. Brietzke et al. ${ }^{(56)}$ in an expert panel consensus, suggested that there is a clinically-relevant association between AR and pediatric CRS, particularly in older children. Sedaghat et al. ${ }^{(57)}$, analyzing a large series of 4044 pediatric cases, observed that AR is one of the most prevalent comorbidity observed in children with CRS (26.9\%) even though a comparison with control group was not provided. Choi et al. ${ }^{(34)}$ showed that age, atopy, AR, and asthma may be predisposing factors for pediatric CRS and recurrent RS. The authors proposed that specific evaluation for allergic diseases should be considered when managing chronic or recurrent RS. More recently, Anamika et al. ${ }^{(58)}$ demonstrated a positive skin prick-test in $53 \%$ of the cases in a cohort of 110 children with CRS; moreover, those with atopy had higher mean Lund-Mackay endoscopic score and Sinus and Nasal Quality of Life Survey score than non-atopic patients.

Huang et al. ${ }^{(59)}$ attempted discrimination among different allergies and reported that mold allergy represents a significant risk factor for development of sinusitis, compared to non-mold allergy, in a case series of 413 
children followed for 5 years. These data suggest that perennial allergy may be a stronger risk factor for CRS compared to seasonal allergy.

On the other hand, some studies suggested a lack of correlation between allergic disease and pediatric CRS. Leo et al. ${ }^{(60)}$, in a report on 351 children affected by CRS, demonstrated that the prevalence of sensitization to aeroallergens was comparable to that of the general pediatric population. No clinical evidence could account for a higher rate of nasal congestion, nor a harsher clinical course, in allergic children ${ }^{(61)}$. Sedaghat et al. ${ }^{(53,62)}$ observed that pediatric patients with AR and CRS seem to have the same aeroallergen sensitivity profile compared to the general pediatric population with AR. Furthermore, the authors did not find a positive association between the number of aeroallergen sensitivities or the presence of atopic comorbidities with the subsequent development of CRS, suggesting that the severity of atopy alone may not be positively predictive of CRS development. These articles were not included in the qualitative analyses due to the type of article.

\subsubsection{Impact of allergy on outcome of chronic rhinosinusitis treatment.}

Ramadan and Hinerman ${ }^{(63)}$, in a retrospective study, noted that children with AR underwent to ESS do not have a poorer outcome respect non allergic one. Nevertheless, children with AR who were on immunotherapy before surgery had an $84 \%$ success rate compared with $62 \%$ for those children with AR who were not treated $(\mathrm{p}=0.022)$. Accordingly, Nathan et al. ${ }^{(64)}$ using the Sinusitis Outcomes Questionnaire (SOQ), demonstrated that immunotherapy was an effective treatment for patients with sinus disease and AR in both children and adults.

About surgery outcomes, Kim et al. ${ }^{(65)}$ and El Sharkawy et al. ${ }^{(66)}$ observed that functional endoscopic sinus surgery in children with CRS and AR does not provide significantly different results compared to children without AR, which is similar to what has been reported in adults ${ }^{(67)}$. On the contrary, in a study by Lee et al. ${ }^{(68)}$, a significantly greater chance of protracted mucopurulent discharge after FESS was registered in patients with AR. The authors assumed that the inflammatory process of nasal allergy, which led to the development of CRS, probably impaired the post-operative wound healing by mucosal congestion, poorfunctioning muco-ciliary clearance and recurrent sneezing that placed pressure on the denuded mucosa. An analogous conclusion was made by $\mathrm{Wu}$ et al. ${ }^{(69)}$ who demonstrated that pediatric patients with positive aeroallergen tests had higher rates of CRS recurrence after ESS and required revision surgery.

\subsection{Allergic fungal sinusitis (AFS) in children.}

AFRS is also present in the paediatric age group and it should be considered as a differential in children presenting with nasal polyposis along with the other causes like ciliary dysmotility disorders and cystic fibrosis ${ }^{(70)}$. There is paucity of data in literature regarding nature, clinical course and its recurrence in children and it was not possible to perform a qualitative analysis. Patro et al. ${ }^{(71)}$ in a single centre prospective study compared features of AFRS in children to adults. The authors concluded that AFRS was more aggressive in children with increased fungal load when compared to adults. The serum IgE levels were also found to be significantly higher in paediatric group, suggesting a higher fungal load, with increased sensitivity to fungal antigen in children. Typically, AFRS in children was less responsive to treatment, with increased recurrence rates.

\section{CONCLUSIONS.}

$\mathrm{AR}$ is a common disease in childhood in industrialized countries and it has a major impact on quality of life and health care resources. Improving the understanding of the pathophysiology of allergy and relationship with its comorbidities is important to correctly develop timed preventive measures as well as perform adequate monitoring and treatment of children with rhinitis. The correct management of allergic diseases can, in fact, decrease the inflammatory response and most likely lead to better control of comorbidities.

Our qualitative analyses demonstrated that there is clear evidence from the lab of a link between allergy and an overall impairment of mechanical and immunological defense function of nasal mucosa against viruses. 
Clinical studies support the hypothesis of a positive association between allergy and viral acute rhinosinusitis/URTI, and only low-quality retrospective studies reached conflicting results. Proof of this is the existence of high-quality investigations showing that anti-allergy treatments may significantly decrease the number and severity of URTI including common colds. We did not find any articles investigating specifically the link between allergy and upper airway involvement by the new coronavirus in children.

Current experimental and clinical experience does not support an etiological link between allergy and post viral rhinosinusitis, ABRS and RARS. At the moment anti-allergy treatments are not advised in these phenotypes even though well design high quality studies are required to improve our knowledge in this field reaching firm conclusions.

Despite the growing knowledge related to allergy and chronic rhinosinusitis in children, it is not yet clear whether AR may promote CRS or if they only share a common pathway of pathogenesis. Even if AR has been positively associated with CRS in several experimental and clinical studies in children, conflicting results have also been reported, probably because of discrepancies in definitions of the disease processes for both CRS and AR and allergy testing methodologies. Researchers have used a variety of techniques to document the presence of sinusitis, such as patient surveys, radiography, CT scan, rhinoscopy, and routine physical examination, and, therefore, the results may not reflect homogeneous populations. In addition, experimental studies and radiological assessment are often prevented by local ethical committees in the pediatric population, for comprehensible reasons. Furthermore, the evidence supports the hypothesis that CRS in children over the age of 13 seems to be more frequently associated with eosinophilic inflammation, whereas in younger patients with CRS neutrophilic inflammation is observed more often ${ }^{(10,11)}$. We did not find investigations analyzing the impact of allergy on CRS based on age, and we believe that more data from large epidemiological studies using explicit criteria is needed.

Although there is no proof of causation, several studies suggested that evaluation of underlying allergies in CRS children is equally recommended, at least to exclude allergy as a concomitant disease and to improve control of symptoms avoiding exposure to known allergens and promoting allergy therapies. Future studies are needed to confirm that anti-allergy treatment may improve outcomes of endoscopic sinus surgery for CRS in children.

We summarized in a practical algorithm our conclusions per each phenotypes of rhinosinusitis in order to elucidate when prompt accurate diagnosis and treatment of allergy is recommended (Figure 2).

\section{IMPACT STATEMENT.}

The unprecedented pandemic by COVID-19 lead to a special attention to vulnerability of children. Clinical and experimental studies suggest a link between allergy and viral acute RS, whereas any correlation may be established with bacterial acute RS. Anti-allergy treatment may prevent and reduce severity of viral acute RS even though any articles investigated specifically the link between allergy and upper airway involvement by the new coronavirus in children. Nevertheless, in this particular era a regular treatment plan should be adopted in allergic children not only to reduce the risk of viral acute RS but also because symptoms may considerably overlap. Finally, although there is no proof of causation of allergy in chronic RS children, anti-allergy treatment might improve outcomes of its specific treatment.

\section{REFERENCES}

1. Seidman M. D., Gurgel R. K., Lin S. Y. et al. (2015). Clinical practice guideline: allergic rhinitis. Otolaryngology-Head and Neck Surgery, 152(1_suppl), S1-S43.

2. Meltzer E. O., \& Hamilos D. L. (2011, May). Rhinosinusitis diagnosis and management for the clinician: a synopsis of recent consensus guidelines. In Mayo Clinic Proceedings (Vol. 86, No. 5, pp. 427-443). Elsevier.

3. Asher M. I., Montefort S., Björkstén B. et al. (2006). Worldwide time trends in the prevalence of symptoms of asthma, allergic rhinoconjunctivitis, and eczema in childhood: ISAAC Phases One and Three repeat multicountry cross-sectional surveys. The Lancet, 368(9537), 733-743. 
4. Wood R. A. (2002). Pediatric asthma. Jama, 288(6), 745-747.

5. Bousquet J., Van Cauwenberge P., \& Khaltaev N. (2001). Allergic rhinitis and its impact on asthma. Journal of allergy and clinical immunology, 108(5), S147-S334.

6. Borish L. (2003). Allergic rhinitis: systemic inflammation and implications for management. Journal of allergy and clinical immunology, 112(6), 1021-1031.

7. Fokkens W. J., Lund V. J., Hopkins C. et al (2020). European position paper on rhinosinusitis and nasal polyps 2020. Rhinology, 58(Supplement 29), 1-464.

8. Tan Y. S. L., Hong C. Y., Chong P. N., Tan E. S. L., Lew Y. J., \& Lin R. T. P. (2006). Knowledge that upper respiratory tract infection resolves on its own is associated with more appropriate health-seeking behavior and antibiotic cognition. Singapore medical journal, 47(6), 518.

9. Garcia M. L., Rey C. C., \& Del Rosal Rabes T. (2016). Pediatric asthma and viral infection. Archivos de Bronconeumología (English Edition), 52(5), 269-273.

10. Larsen J. M., Brix S., Thysen A. H., Birch S., Rasmussen M. A., \& Bisgaard H. (2014). Children with asthma by school age display aberrant immune responses to pathogenic airway bacteria as infants. Journal of allergy and clinical immunology, 133(4), 1008-1013.

11. Parker D., \& Prince A. (2011). Innate immunity in the respiratory epithelium. American journal of respiratory cell and molecular biology, 45(2), 189-201.

12. Waltl E. E., Selb R., Eckl-Dorna J. et al (2018). Betamethasone prevents human rhinovirus-and cigarette smoke-induced loss of respiratory epithelial barrier function. Scientific reports, 8(1), 1-10.

13. Steelant B., Farré R., Wawrzyniak P. et al (2016). Impaired barrier function in patients with house dust mite-induced allergic rhinitis is accompanied by decreased occludin and zonula occludens- 1 expression. Journal of Allergy and Clinical Immunology, 137(4), 1043-1053.

14. Steelant B., Seys S. F., Van Gerven L. et al (2018). Histamine and T helper cytokine-driven epithelial barrier dysfunction in allergic rhinitis. Journal of allergy and clinical immunology, 141(3), 951-963.

15. Ciprandi G., Buscaglia S., Pesce G., Villaggio B., Bagnasco M., \& Canonica G. W. (1993). Allergic subjects express intercellular adhesion molecule-1 (ICAMA or CD54) on epithelial cells of conjunctiva after allergen challenge. Journal of allergy and clinical immunology, 91(3), 783-792.

16. Fasce L., Ciprandi G., Pronzato C. et al (1996). Cetirizine reduces ICAM-I on epithelial cells during nasal minimal persistent inflammation in asymptomatic children with mite-allergic asthma. International archives of allergy and immunology, 109(3), 272-276.

17. Baraldo S., Contoli M., Bazzan E. et al (2012). Deficient antiviral immune responses in childhood: distinct roles of atopy and asthma. Journal of Allergy and Clinical Immunology, 130(6), 1307-1314.

18. Głobińska A., Pawełczyk M., Piechota-Polańczyk A. et al (2017). Impaired virus replication and decreased innate immune responses to viral infections in nasal epithelial cells from patients with allergic rhinitis. Clinical \& Experimental Immunology, 187(1), 100-112.

19. Fenoglio D., Ferrera A., Ferrera F., Sormani M. P., Di Gioacchino M., \& Ciprandi G. (2008). Patients with allergic rhinitis show an allergen-specific interferon-gamma defect. European Journal of Inflammation, 6(2), 87-91.

20. Teach, S. J., Gill, M. A., Togias, A. et al (2015). Preseasonal treatment with either omalizumab or an inhaled corticosteroid boost to prevent fall asthma exacerbations. Journal of Allergy and Clinical Immunology, 136(6), 1476-1485.

21. Karevold G., Kvestad E., Nafstad P., \& Kvaerner K. J. (2006). Respiratory infections in schoolchildren: co-morbidity and risk factors. Archives of disease in childhood, 91(5), 391-395.

22. Ciprandi G., Tosca M. A., \& Fasce L. (2006). Allergic children have more numerous and severe respiratory infections than non-allergic children. Pediatric allergy and immunology, 17(5), 389-391.

23. Kværner K. J., Tambs K., Harris J. R., Mair I. W., \& Magnus P. (1996). Otitis media: relationship to tonsillitis, sinusitis and atopic diseases. International journal of pediatric otorhinolaryngology, 35(2), 127-141.

24. Sütçü M., Acar M., Aktürk H., Hançerli-Törün S., Salman N., \& Somer A. (2016). Recognizing immunodeficiency in children with recurrent infections: What are the predictive factors? The Turkish Journal of Pediatrics, 58(6), 609-615. 
25. Ciprandi G., Tosca M., Passalacqua G., Canonica G. W., Ricca V., \& Landi M. (1999). Continuous antihistamine treatment controls allergic inflammation and reduces respiratory morbidity in children with mite allergy. Allergy, 54(4), 358-365.

26. Barberi S., Bernardo L., D'Auria E. et al (2018). Allergen immunotherapy and respiratory infections in children: an encouraging experience. Minerva pediatrica, 70(1), 1-4.

27. Barberi S., Ciprandi G., Verduci E. et al (2015). Effect of high-dose sublingual immunotherapy on respiratory infections in children allergic to house dust mite. Asia Pacific Allergy, 5(3), 163-169.

28. Chow AW, Benninger MS, Brook I et al (2012). Infectious Diseases Society of America. IDSA clinical practice guideline for acute bacterial rhinosinusitis in children and adults. Clin Infect Dis. 54(8):72-112.

29. Lin S. W., Wang Y. H., Lee M. Y. et al (2012). Clinical spectrum of acute rhinosinusitis among atopic and nonatopic children in Taiwan. International journal of pediatric otorhinolaryngology, 76(1), 70-75.

30. Holzmann D., Willi U., \& Nadal D. (2001). Allergic rhinitis as a risk factor for orbital complication of acute rhinosinusitis in children. American journal of rhinology, 15(6), 387-390.

31. Alho O. P., Karttunen T. J., Karttunen R et al (2003). Subjects with allergic rhinitis show signs of more severely impaired paranasal sinus functioning during viral colds than nonallergic subjects. Allergy, 58(8), 767-771.

32. Lin S. W., Wang S. K., Lu M. C., Wang C. L., \& Koo M. (2019). Acute rhinosinusitis among pediatric patients with allergic rhinitis: A nationwide, population-based cohort study. PloS one, 14(2).

33. Leo G., Incorvaia C., Cazzavillan A., Consonni D., \& Zuccotti G. V. (2018). Could seasonal allergy be a risk factor for acute rhinosinusitis in children? The Journal of Laryngology \& Otology, 132(2), 150-153.

34. Choi S. H., Han M. Y., Ahn Y. M., Park Y. M., Kim C. K., Kim H. H., \& Rha Y. H. (2012). Predisposing factors associated with chronic and recurrent rhinosinusitis in childhood. Allergy, asthma \& immunology research, 4(2), 80-84.

35. Veskitkul J., Vichyanond P., Pacharn P., Visitsunthorn N., \& Jirapongsananuruk O. (2015). Clinical characteristics of recurrent acute rhinosinusitis in children. Asian Pac J Allergy Immunol, 33(4), 276280.

36. Brożek J. L., Bousquet J., Agache I. et al (2017). Allergic Rhinitis and its Impact on Asthma (ARIA) guidelines - 2016 revision. Journal of Allergy and Clinical Immunology, 140(4), 950-958.

37. Veling M. C. (2013). The role of allergy in pediatric rhinosinusitis. Current opinion in otolaryngology \& head and neck surgery, 21(3), 271-276.

38. Chan K. H., Abzug M. J., Coffinet L., Simoes E. A., Cool C., \& Liu A. H. (2004). Chronic rhinosinusitis in young children differs from adults: a histopathology study. The Journal of pediatrics, 144(2), 206212.

39. Berger G., Kogan T., Paker M., Berger-Achituv S., \& Ebner Y. (2011). Pediatric chronic rhinosinusitis histopathology: differences and similarities with the adult form. Otolaryngology-Head and Neck Surgery, 144(1), 85-90.

40. De Corso E., Baroni S., Lucidi D. et al (2015, June). Nasal lavage levels of granulocyte-macrophage colony-stimulating factor and chronic nasal hypereosinophilia. In International forum of allergy \& rhinology (Vol. 5, No. 6, pp. 557-562).

41. De Corso E., Baroni S., Romitelli F. et al (2011). Nasal lavage CCL24 levels correlate with eosinophils trafficking and symptoms in chronic sino-nasal eosinophilic inflammation. Rhinology, 49(2), 174-179.

42. De Corso E., Lucidi D., Battista M. et al (2017). Prognostic value of nasal cytology and clinical factors in nasal polyps development in patients at risk: can the beginning predict the end? In International forum of allergy \& rhinology (Vol. 7, No. 9, pp. 861-867).

43. De Corso E., Baroni S., Battista M. et al (2014). Nasal fluid release of eotaxin-3 and eotaxin-2 in persistent sinonasal eosinophilic inflammation. In International forum of allergy \& rhinology (Vol. 4, No. 8, pp. 617-624).

44. De Corso E., Anzivino R., Galli J. Et al (2019). Antileukotrienes improve naso-ocular symptoms and biomarkers in patients with NARES and asthma. The Laryngoscope, 129(3), 551-557.

45. Chawes B. L. (2011). Upper and lower airway pathology in young children with allergic and non-allergic 
rhinitis. Dan Med Bull, 58(5), B4278.

46. Blair C., Nelson M., Thompson K et al (2001). Allergic inflammation enhances bacterial sinusitis in mice. Journal of allergy and clinical immunology, 108(3), 424-429.

47. Shin Y. H., Kim H. S., Lee E. K. et al (2015). Eosinophil related markers and total immunoglobulin E as a predictive marker for antibiotics response in chronic rhinosinusitis: a case-control study. Annals of Saudi medicine, 35(4), 312-317.

48. Mikolajczyk M., Janukowicz K., Majewska E., \& Baj Z. (2019). Impact of Allergic Rhinitis on Nasal Mucociliary Clearance Time in Children. International archives of allergy and immunology, 179(4), 297-303.

49. Brożek-Madry E., Chmielik L. P., Gałazka A., Rogulska J., Frackiewicz M., \& Biejat A. (2012). Chronic rhinosinusitis in children - Bacteriological analysis in terms of cytological examination. International journal of pediatric otorhinolaryngology, 76(4), 512-522.

50. Bachert C., Gevaert P., \& Van Cauwenberge P. (2002). Staphylococcus aureus enterotoxins: a key in airway disease? Allergy, 57(6), 480-487.

51. Philpott C. M., Erskine S., Hopkins C. et al (2018). Prevalence of asthma, aspirin sensitivity and allergy in chronic rhinosinusitis: data from the UK National Chronic Rhinosinusitis Epidemiology Study. Respiratory research, 19(1), 129.

52. Del Gaudio J. M., Loftus P. A., Hamizan A. W., Harvey R. J., \& Wise S. K. (2017). Central compartment atopic disease. American journal of rhinology \& allergy, 31(4), 228-234.

53. Sedaghat A. R., Phipatanakul W., \& Cunningham M. J. (2013). Atopy and the development of chronic rhinosinusitis in children with allergic rhinitis. The journal of allergy and clinical immunology. In practice, 6(1), 689.

54. Tantimongkolsuk C., Pornrattanarungsee S. Chiewvit P., Visitsunthorn N., Ungkanont K., \& Vichyanond P. (2005). Pediatric sinusitis: symptom profiles with associated atopic conditions. J Med Assoc Thai, 88(Suppl 8), S149-S155.

55. Chandy Z, Ference E, Lee JT. Clinical Guidelines on Chronic Rhinosinusitis in Children. Curr Allergy Asthma Rep. 2019 Feb 22;19(2):14.

56. Brietzke S. E., Shin J. J., Choi S. et al (2014). Clinical consensus statement: pediatric chronic rhinosinusitis. Otolaryngology-Head and Neck Surgery, 151(4), 542-553.

57. Sedaghat A. R., Phipatanakul W., \& Cunningham M. J. (2014). Prevalence of and associations with allergic rhinitis in children with chronic rhinosinusitis. International journal of pediatric otorhinolaryngology, 78(2), 343-347.

58. Anamika A., Chakravarti A., \& Kumar R. (2019). Atopy and quality of life in pediatric chronic rhinosinusitis. American journal of rhinology \& allergy, 33(5), 586-590.

59. Huang S. W. (2000, March). The risk of sinusitis in children with allergic rhinitis. In Allergy Asthma Proc (Vol. 21, No. 2, pp. 85-8).

60. Leo G., Piacentini E., Incorvaia C., Consonni D., \& Frati F. (2007). Chronic rhinosinusitis and allergy. Pediatric Allergy and Immunology, 18, 19-21.

61. Gelardi M., Marchisio P., Caimmi D. et al (2012). Pathophysiology, favoring factors, and associated disorders in otorhinosinusology. Pediatric Allergy and Immunology, 23, 5-16.

62. Sedaghat A. R., Phipatanakul W., \& Cunningham M. J. (2014). Characterization of aeroallergen sensitivities in children with allergic rhinitis and chronic rhinosinusitis. Allergy \& rhinology, 5(3), ar-2014.

63. Ramadan H. H., \& Hinerman R. A. (2006). Outcome of endoscopic sinus surgery in children with allergic rhinitis. American journal of rhinology, 20(4), 438-440.

64. Nathan R. A., Santilli J., Rockwell W., \& Glassheim J. (2004). Effectiveness of immunotherapy for recurring sinusitis associated with allergic rhinitis as assessed by the Sinusitis Outcomes Questionnaire. Annals of Allergy, Asthma \& Immunology, 92(6), 668-672.

65. Kim H. Y., Dhong H. J., Chung S. K., Chung Y. J., \& Min J. Y. (2005). Prognostic factors of pediatric endoscopic sinus surgery. International journal of pediatric otorhinolaryngology, 69(11), 1535-1539.

66. El Sharkawy A. A., Elmorsy S. M., \& Eladl H. M. (2012). Functional endoscopic sinus surgery in 
children: predictive factors of outcome. European Archives of Oto-Rhino-Laryngology, 269(1), 107111.

67. Robinson S., Douglas R., \& Wormald P. J. (2006). The relationship between atopy and chronic rhinosinusitis. American journal of rhinology, 20(6), 625-628.

68. Lee T. J., Liang C. W., Chang P. H., \& Huang C. C. (2009). Risk factors for protracted sinusitis in pediatrics after endoscopic sinus surgery. Auris Nasus Larynx, 36(6), 655-660.

69. Wu P. W., Huang C. C., Yang S. W. et al (2019). Endoscopic sinus surgery for pediatric patients: Prognostic factors related to revision surgery. The Laryngoscope.

70. Thorp B. D., McKinney K. A., Rose A. S., \& Ebert C. S. (2012). Allergic fungal sinusitis in children. Otolaryngologic Clinics of North America, 45(3), 631-642.

71. Patro S. K., Verma R. K., Panda N. K., \& Chakrabarti A. (2015). Understanding paediatric allergic fungal sinusitis: Is it more aggressive?. International journal of pediatric otorhinolaryngology, 79(11), 1876-1880.

Table I. Laboratory evidence linking allergy to impairment of mechanical and immunological function of epithelial barrier.

\begin{tabular}{|c|c|c|c|c|c|}
\hline $\begin{array}{l}\text { Evidence from } \\
\text { the lab linking } \\
\text { allergy to } \\
\text { increased risk } \\
\text { of epithelial } \\
\text { cells viral } \\
\text { infection }\end{array}$ & $\begin{array}{l}\text { Evidence from } \\
\text { the lab linking } \\
\text { allergy to } \\
\text { increased risk } \\
\text { of epithelial } \\
\text { cells viral } \\
\text { infection }\end{array}$ & $\begin{array}{l}\text { Evidence from } \\
\text { the lab linking } \\
\text { allergy to } \\
\text { increased risk } \\
\text { of epithelial } \\
\text { cells viral } \\
\text { infection }\end{array}$ & $\begin{array}{l}\text { Evidence from } \\
\text { the lab linking } \\
\text { allergy to } \\
\text { increased risk } \\
\text { of epithelial } \\
\text { cells viral } \\
\text { infection }\end{array}$ & $\begin{array}{l}\text { Evidence from } \\
\text { the lab linking } \\
\text { allergy to } \\
\text { increased risk } \\
\text { of epithelial } \\
\text { cells viral } \\
\text { infection }\end{array}$ & $\begin{array}{l}\text { Evidence from } \\
\text { the lab linking } \\
\text { allergy to } \\
\text { increased risk } \\
\text { of epithelial } \\
\text { cells viral } \\
\text { infection }\end{array}$ \\
\hline $\begin{array}{l}\text { Author Year } \\
\text { (ref) }\end{array}$ & No. of cases & $\begin{array}{l}\text { Experimental } \\
\text { models }\end{array}$ & Methods & Relevant results & $\begin{array}{l}\text { Association } \\
\text { (Level of } \\
\text { evidence) }\end{array}$ \\
\hline $\begin{array}{l}\text { Waltl et al. } 2018 \\
(12)\end{array}$ & $\mathrm{N}=20$ & $\begin{array}{l}\text { Cultured human } \\
\text { cells from } \\
\text { inferior nasal } \\
\text { turbinate. }\end{array}$ & $\begin{array}{l}\text { Impedance-based } \\
\text { measurement of } \\
\text { respiratory } \\
\text { epithelial barrier } \\
\text { function after } \\
\text { the exposure to } \\
\text { different } \\
\text { concentrations of } \\
\text { House dust mites } \\
\text { (HDM) extract. }\end{array}$ & $\begin{array}{l}\text { Dose dependent } \\
\text { decrease of } \\
\text { barrier function, } \\
\text { alteration of } \\
\text { morphology and } \\
\text { thickness of the } \\
\text { epithelium, } \\
\text { decrease of } \\
\text { ciliary beat } \\
\text { frequency and } \\
\text { tight junction } \\
\text { expression, } \\
\text { facilitating } \\
\text { pathogen } \\
\text { permeability. }\end{array}$ & Yes (Level V) \\
\hline
\end{tabular}




\begin{tabular}{|c|c|c|c|c|c|}
\hline $\begin{array}{l}\text { Evidence from } \\
\text { the lab linking } \\
\text { allergy to } \\
\text { increased risk } \\
\text { of epithelial } \\
\text { cells viral } \\
\text { infection }\end{array}$ & $\begin{array}{l}\text { Evidence from } \\
\text { the lab linking } \\
\text { allergy to } \\
\text { increased risk } \\
\text { of epithelial } \\
\text { cells viral } \\
\text { infection }\end{array}$ & $\begin{array}{l}\text { Evidence from } \\
\text { the lab linking } \\
\text { allergy to } \\
\text { increased risk } \\
\text { of epithelial } \\
\text { cells viral } \\
\text { infection }\end{array}$ & $\begin{array}{l}\text { Evidence from } \\
\text { the lab linking } \\
\text { allergy to } \\
\text { increased risk } \\
\text { of epithelial } \\
\text { cells viral } \\
\text { infection }\end{array}$ & $\begin{array}{l}\text { Evidence from } \\
\text { the lab linking } \\
\text { allergy to } \\
\text { increased risk } \\
\text { of epithelial } \\
\text { cells viral } \\
\text { infection }\end{array}$ & $\begin{array}{l}\text { Evidence from } \\
\text { the lab linking } \\
\text { allergy to } \\
\text { increased risk } \\
\text { of epithelial } \\
\text { cells viral } \\
\text { infection }\end{array}$ \\
\hline $\begin{array}{l}\text { Steelant et al. } \\
2018(14)\end{array}$ & $\begin{array}{l}\mathrm{N}=9 \text { allergic } \\
\text { rhinitis; } 6 \\
\text { idiopathic } \\
\text { rhinitis; } 10 \\
\text { controls. }\end{array}$ & $\begin{array}{l}\text { Cultures of } \\
\text { primary nasal } \\
\text { epithelial cells } \\
\text { from healthy } \\
\text { control exposed } \\
\text { to nasal } \\
\text { secretions of } \\
\text { allergic vs } \\
\text { non-allergic } \\
\text { patients. }\end{array}$ & $\begin{array}{l}\text { Measurement of } \\
\text { transepithelial } \\
\text { electrical } \\
\text { resistance, } \\
\text { paracellular flux } \\
\text { of fluorescein } \\
\text { isothiocyanate- } \\
\text { dextran } 4 \text { and } \\
\text { mRNA } \\
\text { expression of } \\
\text { tight junctions. }\end{array}$ & $\begin{array}{l}\text { Histamine and } \\
\text { nasal secretions } \\
\text { from AR, but } \\
\text { not from } \\
\text { idiopathic } \\
\text { rhinitis patients, } \\
\text { rapidly decrease } \\
\text { in trans-tissue } \\
\text { resistance. } \\
\text { Pre-treatment } \\
\text { with histamine } \\
\text { receptor-1 } \\
\text { antagonist, } \\
\text { azelastine, } \\
\text { prevented the } \\
\text { early effect of } \\
\text { nasal secretions } \\
\text { of AR patients } \\
\text { on epithelial } \\
\text { integrity. }\end{array}$ & Yes (Level V) \\
\hline
\end{tabular}




\begin{tabular}{|c|c|c|c|c|c|}
\hline $\begin{array}{l}\text { Evidence from } \\
\text { the lab linking } \\
\text { allergy to } \\
\text { increased risk } \\
\text { of epithelial } \\
\text { cells viral } \\
\text { infection }\end{array}$ & $\begin{array}{l}\text { Evidence from } \\
\text { the lab linking } \\
\text { allergy to } \\
\text { increased risk } \\
\text { of epithelial } \\
\text { cells viral } \\
\text { infection }\end{array}$ & $\begin{array}{l}\text { Evidence from } \\
\text { the lab linking } \\
\text { allergy to } \\
\text { increased risk } \\
\text { of epithelial } \\
\text { cells viral } \\
\text { infection }\end{array}$ & $\begin{array}{l}\text { Evidence from } \\
\text { the lab linking } \\
\text { allergy to } \\
\text { increased risk } \\
\text { of epithelial } \\
\text { cells viral } \\
\text { infection }\end{array}$ & $\begin{array}{l}\text { Evidence from } \\
\text { the lab linking } \\
\text { allergy to } \\
\text { increased risk } \\
\text { of epithelial } \\
\text { cells viral } \\
\text { infection }\end{array}$ & $\begin{array}{l}\text { Evidence from } \\
\text { the lab linking } \\
\text { allergy to } \\
\text { increased risk } \\
\text { of epithelial } \\
\text { cells viral } \\
\text { infection }\end{array}$ \\
\hline $\begin{array}{l}\text { Fenoglio et al. } \\
2008 \text { (19) }\end{array}$ & $\begin{array}{l}\mathrm{N}=41 \mathrm{AR} \\
\text { patients }\end{array}$ & $\begin{array}{l}\text { Peripheral blood } \\
\text { mononuclear } \\
\text { cells (PBMC) } \\
\text { producing } \\
\text { IFN-in vitro. }\end{array}$ & $\begin{array}{l}\text { IFN- } \gamma \text {-specific } \\
\text { producing cells } \\
\text { were stimulated } \\
\text { with Phyto- } \\
\text { haemagglutinin } \\
(\mathrm{PHA}) \text {, causal } \\
\text { pollen, and } \\
\text { House Dust Mite } \\
\text { (HDM). IFN- } \gamma \\
\text { production was } \\
\text { assessed by } \\
\text { cytokine } \\
\text { ELISPOT. }\end{array}$ & $\begin{array}{l}\text { IFN- } \gamma \\
\text { production of } \\
\text { PBMC } \\
\text { stimulated by } \\
\text { specific pollen } \\
\text { was significantly } \\
\text { lower than } \\
\text { IFN- } \gamma \\
\text { production of } \\
\text { PBMC } \\
\text { stimulated by } \\
\text { HDM. IFN- } \gamma \\
\text { production of } \\
\text { PBMC } \\
\text { stimulated by } \\
\text { specific pollen } \\
\text { was significantly } \\
\text { lower than } \\
\text { IFN- } \gamma \\
\text { production of } \\
\text { PBMC } \\
\text { stimulated by } \\
\text { PHA. }\end{array}$ & Yes (Level V) \\
\hline
\end{tabular}




\begin{tabular}{|c|c|c|c|c|c|}
\hline $\begin{array}{l}\text { Evidence from } \\
\text { the lab linking } \\
\text { allergy to } \\
\text { increased risk } \\
\text { of epithelial } \\
\text { cells viral } \\
\text { infection }\end{array}$ & $\begin{array}{l}\text { Evidence from } \\
\text { the lab linking } \\
\text { allergy to } \\
\text { increased risk } \\
\text { of epithelial } \\
\text { cells viral } \\
\text { infection }\end{array}$ & $\begin{array}{l}\text { Evidence from } \\
\text { the lab linking } \\
\text { allergy to } \\
\text { increased risk } \\
\text { of epithelial } \\
\text { cells viral } \\
\text { infection }\end{array}$ & $\begin{array}{l}\text { Evidence from } \\
\text { the lab linking } \\
\text { allergy to } \\
\text { increased risk } \\
\text { of epithelial } \\
\text { cells viral } \\
\text { infection }\end{array}$ & $\begin{array}{l}\text { Evidence from } \\
\text { the lab linking } \\
\text { allergy to } \\
\text { increased risk } \\
\text { of epithelial } \\
\text { cells viral } \\
\text { infection }\end{array}$ & $\begin{array}{l}\text { Evidence from } \\
\text { the lab linking } \\
\text { allergy to } \\
\text { increased risk } \\
\text { of epithelial } \\
\text { cells viral } \\
\text { infection }\end{array}$ \\
\hline $\begin{array}{l}\text { Teach et al. } 2015 \\
(20)\end{array}$ & $\begin{array}{l}\mathrm{N}=478 \text { children } \\
(10.2 \pm 2.93 \mathrm{yr})\end{array}$ & $\begin{array}{l}\text { Peripheral blood } \\
\text { mononuclear cell } \\
\text { cultures } \\
\text { incubated } \\
\text { ex-vivo with } \\
\text { rhinovirus. }\end{array}$ & $\begin{array}{l}\text { Measuring INF- } \alpha \\
\text { in supernatants } \\
\text { of PBMCs } \\
\text { cultures } \\
\text { obtained from a } \\
\text { subset of } \\
\text { subjects (n = } \\
\text { 87) incubated } \\
\text { ex-vivo with } \\
\text { rhinovirusin } \\
\text { patients treated } \\
\text { or not with } \\
\text { Omalizumab. }\end{array}$ & $\begin{array}{l}\text { The group } \\
\text { treated with } \\
\text { anti-IgE had } \\
\text { improved INF- } \alpha \\
\text { production after } \\
\text { virus infection } \\
\text { suggesting } \\
\text { restoring of the } \\
\text { impaired } \\
\text { interferon } \\
\text { response and } \\
\text { increasing } \\
\text { antiviral } \\
\text { immunity and } \\
\text { suggesting that } \\
\text { anti-IgE may } \\
\text { prevent upper } \\
\text { and lower } \\
\text { respiratory } \\
\text { infections and } \\
\text { asthma } \\
\text { exacerbations }\end{array}$ & Yes (Level V) \\
\hline
\end{tabular}

Table II: Articles investigating clinical association between allergy and upper respiratory infections.

\begin{tabular}{|c|c|c|c|c|c|}
\hline $\begin{array}{l}\text { Clinical } \\
\text { evidence } \\
\text { linking allergy } \\
\text { to risk of } \\
\text { upper } \\
\text { respiratory } \\
\text { tract infections }\end{array}$ & $\begin{array}{l}\text { Clinical } \\
\text { evidence } \\
\text { linking allergy } \\
\text { to risk of } \\
\text { upper } \\
\text { respiratory } \\
\text { tract infections }\end{array}$ & $\begin{array}{l}\text { Clinical } \\
\text { evidence } \\
\text { linking allergy } \\
\text { to risk of } \\
\text { upper } \\
\text { respiratory } \\
\text { tract infections }\end{array}$ & $\begin{array}{l}\text { Clinical } \\
\text { evidence } \\
\text { linking allergy } \\
\text { to risk of } \\
\text { upper } \\
\text { respiratory } \\
\text { tract infections }\end{array}$ & $\begin{array}{l}\text { Clinical } \\
\text { evidence } \\
\text { linking allergy } \\
\text { to risk of } \\
\text { upper } \\
\text { respiratory } \\
\text { tract infections }\end{array}$ & $\begin{array}{l}\text { Clinical } \\
\text { evidence } \\
\text { linking allergy } \\
\text { to risk of } \\
\text { upper } \\
\text { respiratory } \\
\text { tract infections }\end{array}$ \\
\hline $\begin{array}{l}\text { Author Year } \\
\text { (ref) }\end{array}$ & Type of article & $\begin{array}{l}\text { No. of cases } \\
\text { (mean age) }\end{array}$ & Methods & Relevant results & $\begin{array}{l}\text { Association } \\
\text { (Level of } \\
\text { evidence) }\end{array}$ \\
\hline $\begin{array}{l}\text { Karevold et al. } \\
2006(21)\end{array}$ & $\begin{array}{l}\text { Cross-sectional } \\
\text { survey. }\end{array}$ & $\mathrm{N}=5125(10 \mathrm{yr})$ & $\begin{array}{l}\text { Assess } \\
\text { co-morbidity and } \\
\text { risk factors for } \\
\text { recurrent upper } \\
\text { and lower } \\
\text { respiratory } \\
\text { infections. }\end{array}$ & $\begin{array}{l}\text { Atopic disease } \\
\text { was a } \\
\text { constitutional } \\
\text { risk factor, for } \\
\text { upper and lower } \\
\text { airway } \\
\text { infections. }\end{array}$ & Yes (Level IV) \\
\hline
\end{tabular}




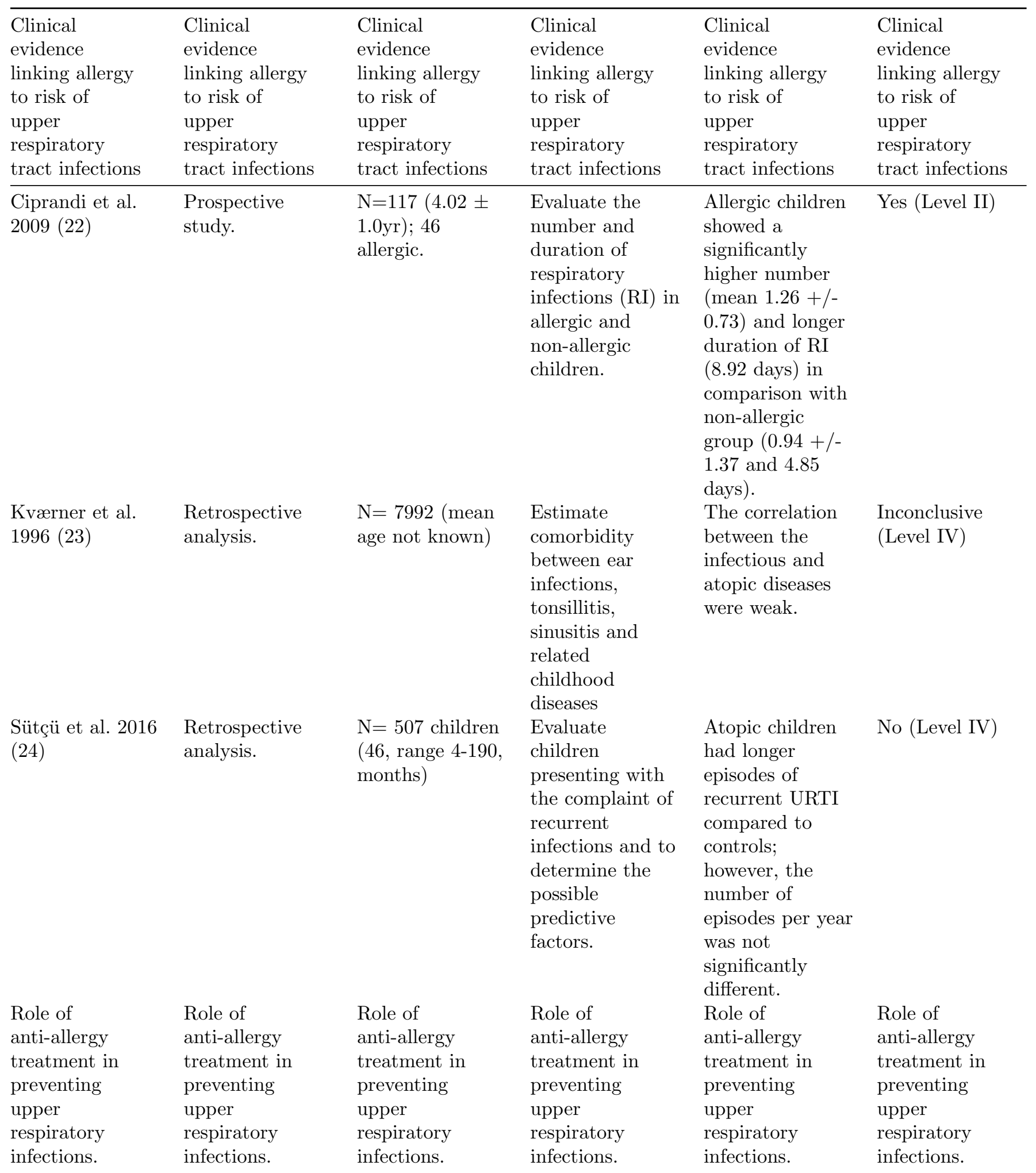




\begin{tabular}{|c|c|c|c|c|c|}
\hline $\begin{array}{l}\text { Clinical } \\
\text { evidence } \\
\text { linking allergy } \\
\text { to risk of } \\
\text { upper } \\
\text { respiratory } \\
\text { tract infections }\end{array}$ & $\begin{array}{l}\text { Clinical } \\
\text { evidence } \\
\text { linking allergy } \\
\text { to risk of } \\
\text { upper } \\
\text { respiratory } \\
\text { tract infections }\end{array}$ & $\begin{array}{l}\text { Clinical } \\
\text { evidence } \\
\text { linking allergy } \\
\text { to risk of } \\
\text { upper } \\
\text { respiratory } \\
\text { tract infections }\end{array}$ & $\begin{array}{l}\text { Clinical } \\
\text { evidence } \\
\text { linking allergy } \\
\text { to risk of } \\
\text { upper } \\
\text { respiratory } \\
\text { tract infections }\end{array}$ & $\begin{array}{l}\text { Clinical } \\
\text { evidence } \\
\text { linking allergy } \\
\text { to risk of } \\
\text { upper } \\
\text { respiratory } \\
\text { tract infections }\end{array}$ & $\begin{array}{l}\text { Clinical } \\
\text { evidence } \\
\text { linking allergy } \\
\text { to risk of } \\
\text { upper } \\
\text { respiratory } \\
\text { tract infections }\end{array}$ \\
\hline Fasce 1996 (16) & $\begin{array}{l}\text { Double-blind, } \\
\text { placebo } \\
\text { controlled } \\
\text { randomized } \\
\text { study. }\end{array}$ & $\begin{array}{l}\mathrm{N}=20 \text { children } \\
(5-14 \text { years old }) \\
\text { with mite } \\
\text { allergy. }\end{array}$ & $\begin{array}{l}\text { Cetirizine vs } \\
\text { placebo for } 15 \\
\text { days. Nasal } \\
\text { scrapings were } \\
\text { performed to } \\
\text { evaluate } \\
\text { inflammatory } \\
\text { cell infiltration } \\
\text { and ICAM-I } \\
\text { expression on } \\
\text { epithelial cells. }\end{array}$ & $\begin{array}{l}\text { Cetirizine- } \\
\text { treated children } \\
\text { showed a } \\
\text { significant } \\
\text { reduction (or } \\
\text { even total } \\
\text { absence) of } \\
\text { ICAM-I } \\
\text { expression on } \\
\text { epithelial cells } \\
\text { (p=0.002) and a } \\
\text { reduction trend } \\
\text { in inflammatory } \\
\text { cell counts } \\
\text { compared with } \\
\text { placebo }\end{array}$ & Yes (Level I) \\
\hline $\begin{array}{l}\text { Barebri et al } \\
2015(27)\end{array}$ & $\begin{array}{l}\text { Prospective case } \\
\text { control } \\
\text { observational } \\
\text { stydy, } \\
\text { not-randomised. }\end{array}$ & $\begin{array}{l}\mathrm{N}=40 \mathrm{HDM} \\
\text { allergic children } \\
(9.3 \mathrm{yr})\end{array}$ & $\begin{array}{l}\text { Patients were } \\
\text { subdivided in } 2 \\
\text { groups: } 20 \\
\text { treated by } \\
\text { symptomatic } \\
\text { drugs and } 20 \text { by } \\
\text { high-dose } \\
\text { HDM-SLIT. }\end{array}$ & $\begin{array}{l}\text { SLIT-treated } \\
\text { children had } \\
\text { significantly (p } \\
=0.01) \text { less RI } \\
\text { episodes }(3.5) \\
\text { than control } \\
\text { group }(5.45) \text {. }\end{array}$ & Yes (Level II) \\
\hline
\end{tabular}




\begin{tabular}{|c|c|c|c|c|c|}
\hline $\begin{array}{l}\text { Clinical } \\
\text { evidence } \\
\text { linking allergy } \\
\text { to risk of } \\
\text { upper } \\
\text { respiratory } \\
\text { tract infections }\end{array}$ & $\begin{array}{l}\text { Clinical } \\
\text { evidence } \\
\text { linking allergy } \\
\text { to risk of } \\
\text { upper } \\
\text { respiratory } \\
\text { tract infections }\end{array}$ & $\begin{array}{l}\text { Clinical } \\
\text { evidence } \\
\text { linking allergy } \\
\text { to risk of } \\
\text { upper } \\
\text { respiratory } \\
\text { tract infections }\end{array}$ & $\begin{array}{l}\text { Clinical } \\
\text { evidence } \\
\text { linking allergy } \\
\text { to risk of } \\
\text { upper } \\
\text { respiratory } \\
\text { tract infections }\end{array}$ & $\begin{array}{l}\text { Clinical } \\
\text { evidence } \\
\text { linking allergy } \\
\text { to risk of } \\
\text { upper } \\
\text { respiratory } \\
\text { tract infections }\end{array}$ & $\begin{array}{l}\text { Clinical } \\
\text { evidence } \\
\text { linking allergy } \\
\text { to risk of } \\
\text { upper } \\
\text { respiratory } \\
\text { tract infections }\end{array}$ \\
\hline $\begin{array}{l}\text { Barberi } 2018 \\
(26)\end{array}$ & $\begin{array}{l}\text { Retrospective } \\
\text { analysis. }\end{array}$ & $\begin{array}{l}\mathrm{N}=33 \mathrm{HDM} \\
\text { allergic children } \\
(9.3 \mathrm{yr}) .\end{array}$ & $\begin{array}{l}\text { Investigate } \\
\text { whether } 3 \text { year } \\
\text { high-dose } \\
\text { HDM-SLIT } \\
\text { affects } \\
\text { respiratory } \\
\text { infections in } \\
\text { children with } \\
\text { allergic rhinitis. }\end{array}$ & $\begin{array}{l}\text { SLIT-treated } \\
\text { children had } \\
\text { significantly } \\
\text { fewer RI } \\
\text { episodes than } \\
\text { symptomatically } \\
\text { treated children. } \\
\text { In addition, they } \\
\text { had less fever } \\
\text { and took fewer } \\
\text { medications, } \\
\text { such as } \\
\text { antibiotics and } \\
\text { antipyretics. }\end{array}$ & Yes (Level IV) \\
\hline
\end{tabular}

HDM: house dust mites; SLIT: sub-lingual immunotherapy; URTI: upper respiratory tract infections; RI: respiratory infections. RI: respiratory infections

Table III Evidence from the lab linking allergy to CRS in children.

\begin{tabular}{|c|c|c|c|c|c|}
\hline $\begin{array}{l}\text { Laboratory } \\
\text { evidence } \\
\text { linking allergy } \\
\text { to risk of CRS }\end{array}$ & $\begin{array}{l}\text { Laboratory } \\
\text { evidence } \\
\text { linking allergy } \\
\text { to risk of CRS }\end{array}$ & $\begin{array}{l}\text { Laboratory } \\
\text { evidence } \\
\text { linking allergy } \\
\text { to risk of CRS }\end{array}$ & $\begin{array}{l}\text { Laboratory } \\
\text { evidence } \\
\text { linking allergy } \\
\text { to risk of CRS }\end{array}$ & $\begin{array}{l}\text { Laboratory } \\
\text { evidence } \\
\text { linking allergy } \\
\text { to risk of CRS }\end{array}$ & $\begin{array}{l}\text { Laboratory } \\
\text { evidence } \\
\text { linking allergy } \\
\text { to risk of CRS }\end{array}$ \\
\hline $\begin{array}{l}\text { Author Year ( ) } \\
\text { ref }\end{array}$ & No. of cases & $\begin{array}{l}\text { Experimental } \\
\text { models }\end{array}$ & Methods & Relevant results & $\begin{array}{l}\text { Association } \\
\text { (Level of } \\
\text { evidence) }\end{array}$ \\
\hline $\begin{array}{l}\text { Chawes, } 2011 \\
(45)\end{array}$ & $\begin{array}{l}\mathrm{N}=411 \text { children } \\
\text { with AR, non } \\
\text { AR and healthy } \\
\text { controls }(6 \mathrm{yr})\end{array}$ & $\begin{array}{l}\text { Nasal airway } \\
\text { patency was } \\
\text { assessed by } \\
\text { acoustic } \\
\text { rhinometry. }\end{array}$ & $\begin{array}{l}\text { Acoustic } \\
\text { rhinometry was } \\
\text { performed twice } \\
\text { in the child's } 6 \text { th } \\
\text { year of life, with } \\
\text { or without } \\
\text { allergy. Nasal } \\
\text { eosinophilia was } \\
\text { assessed by nasal } \\
\text { scraping. }\end{array}$ & $\begin{array}{l}\text { Nasal } \\
\text { eosinophilia } \\
\text { correlated with } \\
\text { irreversible nasal } \\
\text { airway } \\
\text { obstruction, in } \\
\text { allergic children } \\
\text { already at age } 6 \\
\text { years. No change } \\
\text { in nasal airway } \\
\text { patency were } \\
\text { observed in } \\
\text { non-allergic } \\
\text { rhinitis. }\end{array}$ & Yes (Level III) \\
\hline
\end{tabular}




\begin{tabular}{|c|c|c|c|c|c|}
\hline $\begin{array}{l}\text { Laboratory } \\
\text { evidence } \\
\text { linking allergy } \\
\text { to risk of } C R S\end{array}$ & $\begin{array}{l}\text { Laboratory } \\
\text { evidence } \\
\text { linking allergy } \\
\text { to risk of } C R S\end{array}$ & $\begin{array}{l}\text { Laboratory } \\
\text { evidence } \\
\text { linking allergy } \\
\text { to risk of } C R S\end{array}$ & $\begin{array}{l}\text { Laboratory } \\
\text { evidence } \\
\text { linking allergy } \\
\text { to risk of } C R S\end{array}$ & $\begin{array}{l}\text { Laboratory } \\
\text { evidence } \\
\text { linking allergy } \\
\text { to risk of } C R S\end{array}$ & $\begin{array}{l}\text { Laboratory } \\
\text { evidence } \\
\text { linking allergy } \\
\text { to risk of } C R S\end{array}$ \\
\hline $\begin{array}{l}\text { Blair et al. } 2001 \\
(46)\end{array}$ & $\mathrm{N} / \mathrm{A}$ & $\begin{array}{l}\text { Mouse sensitized } \\
\text { to ovalbumin by } \\
\text { intraperitoneal } \\
\text { injection. }\end{array}$ & $\begin{array}{l}\text { Sinuses of the } \\
\text { mouse were } \\
\text { infected by S. } \\
\text { Pneumoniae, } \\
\text { with or without } \\
\text { concomitant } \\
\text { administration } \\
\text { of ovalbumin to } \\
\text { induce or not } \\
\text { aller- } \\
\text { gic inflammation. }\end{array}$ & $\begin{array}{l}\text { Mice with } \\
\text { allergic } \\
\text { sino-nasal } \\
\text { inflammation } \\
\text { had significantly } \\
\text { more bacteria } \\
\text { and significantly } \\
\text { more } \\
\text { inflammation (as } \\
\text { indicated by } \\
\text { neutrophil, } \\
\text { eosinophil, and } \\
\text { mononuclear } \\
\text { influx) into the } \\
\text { sinus respect the } \\
\text { non-allergic } \\
\text { ones. }\end{array}$ & Yes (Level V) \\
\hline $\begin{array}{l}\text { Shin et al. } 2015 \\
(47)\end{array}$ & $\begin{array}{l}\mathrm{N}=36 \mathrm{CRS} \\
\text { responders vs } 22 \\
\text { CRS } \\
\text { non-responders, } \\
22 \text { healthy } \\
\text { controls. } \\
(\text { age }<15 \mathrm{yr})\end{array}$ & Serum analyses. & $\begin{array}{l}\text { Skin prick tests } \\
\text { were performed } \\
\text { along with } \\
\text { serum total IgE, } \\
\text { total eosinophil } \\
\text { count (TEC), } \\
\text { serum eosinophil } \\
\text { cationic protein } \\
\text { (ECP) level, and } \\
\text { ImmunoCAP } \\
\text { analysis for } \\
\text { common } \\
\text { allergens. }\end{array}$ & $\begin{array}{l}\text { TEC, ECP, and } \\
\text { total IgE levels } \\
\text { were significantly } \\
\text { higher in the } \\
\text { non-responder } \\
\text { group than in } \\
\text { the responder } \\
\text { and control } \\
\text { groups. }\end{array}$ & Yes (Level III) \\
\hline $\begin{array}{l}\text { Mikolajczyk et } \\
\text { al. } 2019 \text { (48) }\end{array}$ & $\begin{array}{l}\mathrm{N}=842 \mathrm{AR} \\
\text { children and } 96 \\
\text { controls. }\end{array}$ & \%EOSns. MCT. & $\begin{array}{l}\text { All patients } \\
\text { underwent } \\
\text { saccharin and } \\
\text { skin prick tests, } \\
\text { nasal smear } \\
\text { eosinophilia, } \\
\text { total and specific } \\
\text { IgE serum } \\
\text { concentration } \\
\text { and MCT } \\
\text { measurement. }\end{array}$ & $\begin{array}{l}\text { Nasal MCT was } \\
\text { significantly } \\
\text { longer in AR } \\
\text { patients than } \\
\text { controls. } \\
\text { \%EOSns were } \\
\text { significantly } \\
\text { higher in } \\
\text { patients than } \\
\text { controls. A } \\
\text { weak, but } \\
\text { significant } \\
\text { correlation was } \\
\text { observed } \\
\text { between } \\
\text { \%EOSns and } \\
\text { MCT. }\end{array}$ & Yes (Level III) \\
\hline
\end{tabular}




\begin{tabular}{|c|c|c|c|c|c|}
\hline $\begin{array}{l}\text { Laboratory } \\
\text { evidence } \\
\text { linking allergy } \\
\text { to risk of CRS }\end{array}$ & $\begin{array}{l}\text { Laboratory } \\
\text { evidence } \\
\text { linking allergy } \\
\text { to risk of } C R S\end{array}$ & $\begin{array}{l}\text { Laboratory } \\
\text { evidence } \\
\text { linking allergy } \\
\text { to risk of CRS }\end{array}$ & $\begin{array}{l}\text { Laboratory } \\
\text { evidence } \\
\text { linking allergy } \\
\text { to risk of } C R S\end{array}$ & $\begin{array}{l}\text { Laboratory } \\
\text { evidence } \\
\text { linking allergy } \\
\text { to risk of } C R S\end{array}$ & $\begin{array}{l}\text { Laboratory } \\
\text { evidence } \\
\text { linking allergy } \\
\text { to risk of } C R S\end{array}$ \\
\hline $\begin{array}{l}\text { Brożek-Madry et } \\
\text { al. } 2012(49)\end{array}$ & $\begin{array}{l}\mathrm{N}=64 \text { patients } \\
\text { with chronic } \\
\text { rhinosinusitis } \\
\text { without polyps } \\
\text { and } 30 \text { controls } \\
\text { (age } 5-18 \mathrm{yr} \text { ). }\end{array}$ & $\begin{array}{l}\text { Epithelial } \\
\text { cultures (middle } \\
\text { meatal cells). }\end{array}$ & $\begin{array}{l}\text { Middle meatal } \\
\text { culture and } \\
\text { cytological } \\
\text { examination } \\
\text { from the inferior } \\
\text { nasal concha and } \\
\text { middle meatus. }\end{array}$ & $\begin{array}{l}\text { The most } \\
\text { common strains } \\
\text { of bacteria found } \\
\text { in patients with } \\
\text { CRS were } \\
\text { associated with a } \\
\text { higher } \\
\text { percentage of } \\
\text { eosinophils in } \\
\text { cytology and } \\
\text { high prevalence } \\
\text { in atopic } \\
\text { patients. }\end{array}$ & Yes (Level V) \\
\hline
\end{tabular}

AR: allergic rhinitis; CRS: chronic rhinosinusitis; MCT: mucociliary transport time: \%EOSns: percentage of eosinophils in nasal smear.

Table IV: Clinical evidence linking allergy to CRS in children.

\begin{tabular}{|c|c|c|c|c|c|}
\hline $\begin{array}{l}\text { Clinical } \\
\text { evidence } \\
\text { linking allergy } \\
\text { to risk of CRS } \\
\text { in children }\end{array}$ & $\begin{array}{l}\text { Clinical } \\
\text { evidence } \\
\text { linking allergy } \\
\text { to risk of CRS } \\
\text { in children }\end{array}$ & $\begin{array}{l}\text { Clinical } \\
\text { evidence } \\
\text { linking allergy } \\
\text { to risk of CRS } \\
\text { in children }\end{array}$ & $\begin{array}{l}\text { Clinical } \\
\text { evidence } \\
\text { linking allergy } \\
\text { to risk of CRS } \\
\text { in children }\end{array}$ & $\begin{array}{l}\text { Clinical } \\
\text { evidence } \\
\text { linking allergy } \\
\text { to risk of CRS } \\
\text { in children }\end{array}$ & $\begin{array}{l}\text { Clinical } \\
\text { evidence } \\
\text { linking allergy } \\
\text { to risk of CRS } \\
\text { in children }\end{array}$ \\
\hline $\begin{array}{l}\text { Author Year ( ) } \\
\text { ref }\end{array}$ & Type of article & $\begin{array}{l}\text { No. of cases } \\
\text { (mean age) }\end{array}$ & Methods & Relevant results & $\begin{array}{l}\text { Association } \\
\text { (Level of } \\
\text { evidence) }\end{array}$ \\
\hline $\begin{array}{l}\text { Sedaghat et al. } \\
2014(57)\end{array}$ & $\begin{array}{l}\text { Retrospective } \\
\text { analysis. }\end{array}$ & $\begin{array}{l}\mathrm{N}=4044 \\
\text { children with } \\
\mathrm{CRS}(8.9 \mathrm{yr}) .\end{array}$ & $\begin{array}{l}\text { Retrospective } \\
\text { review of } \\
\text { children } \\
\text { diagnosed as } \\
\text { uncomplicated } \\
\text { CRS by an } \\
\text { otolaryngology } \\
\text { or allergy office } \\
\text { evaluation }\end{array}$ & $\begin{array}{l}\text { Comorbidities } \\
\text { observed in CRS } \\
\text { children were } \\
\text { primary ciliary } \\
\text { dyskinesia } \\
(0.2 \%) \text {, cystic } \\
\text { fibrosis (4.1\%), } \\
\text { immunologic } \\
\text { disorder }(12.3 \%) \\
\text { and AR }(26.9 \%) \text {. }\end{array}$ & $\begin{array}{l}\text { Inconclusive } \\
\text { (Level IV) }\end{array}$ \\
\hline
\end{tabular}




\begin{tabular}{|c|c|c|c|c|c|}
\hline $\begin{array}{l}\text { Clinical } \\
\text { evidence } \\
\text { linking allergy } \\
\text { to risk of CRS } \\
\text { in children }\end{array}$ & $\begin{array}{l}\text { Clinical } \\
\text { evidence } \\
\text { linking allergy } \\
\text { to risk of CRS } \\
\text { in children }\end{array}$ & $\begin{array}{l}\text { Clinical } \\
\text { evidence } \\
\text { linking allergy } \\
\text { to risk of CRS } \\
\text { in children }\end{array}$ & $\begin{array}{l}\text { Clinical } \\
\text { evidence } \\
\text { linking allergy } \\
\text { to risk of CRS } \\
\text { in children }\end{array}$ & $\begin{array}{l}\text { Clinical } \\
\text { evidence } \\
\text { linking allergy } \\
\text { to risk of CRS } \\
\text { in children }\end{array}$ & $\begin{array}{l}\text { Clinical } \\
\text { evidence } \\
\text { linking allergy } \\
\text { to risk of CRS } \\
\text { in children }\end{array}$ \\
\hline $\begin{array}{l}\text { Choi et al. } 2012 \\
(34)\end{array}$ & $\begin{array}{l}\text { Prospective } \\
\text { study. }\end{array}$ & $\begin{array}{l}\mathrm{N}=296(<13 \mathrm{yr}) \\
\text { with } \mathrm{RS}\end{array}$ & $\begin{array}{l}\text { To evaluate } \\
\text { predisposing } \\
\text { factors for } \\
\text { chronic and } \\
\text { recurrent } \\
\text { rhinosinusitis } \\
(\mathrm{RS}) .\end{array}$ & $\begin{array}{l}\text { The prevalence } \\
\text { of AR, atopy, } \\
\text { and asthma were } \\
\text { significantly } \\
\text { higher in } \\
\text { patients with } \\
\text { CRS and } \\
\text { recurrent RS } \\
\text { than those with } \\
\text { acute and } \\
\text { subacute RS. }\end{array}$ & Yes (Level II) \\
\hline
\end{tabular}




\begin{tabular}{|c|c|c|c|c|c|}
\hline $\begin{array}{l}\text { Clinical } \\
\text { evidence } \\
\text { linking allergy } \\
\text { to risk of CRS } \\
\text { in children }\end{array}$ & $\begin{array}{l}\text { Clinical } \\
\text { evidence } \\
\text { linking allergy } \\
\text { to risk of CRS } \\
\text { in children }\end{array}$ & $\begin{array}{l}\text { Clinical } \\
\text { evidence } \\
\text { linking allergy } \\
\text { to risk of CRS } \\
\text { in children }\end{array}$ & $\begin{array}{l}\text { Clinical } \\
\text { evidence } \\
\text { linking allergy } \\
\text { to risk of CRS } \\
\text { in children }\end{array}$ & $\begin{array}{l}\text { Clinical } \\
\text { evidence } \\
\text { linking allergy } \\
\text { to risk of CRS } \\
\text { in children }\end{array}$ & $\begin{array}{l}\text { Clinical } \\
\text { evidence } \\
\text { linking allergy } \\
\text { to risk of CRS } \\
\text { in children }\end{array}$ \\
\hline $\begin{array}{l}\text { Leo et al. } 2007 \\
(60)\end{array}$ & $\begin{array}{l}\text { Cross-sectional } \\
\text { study }\end{array}$ & $\begin{array}{l}\mathrm{N}=351 \text { children } \\
\text { with } \mathrm{CRS}(5.23 \\
\pm 2.11 \mathrm{yr})\end{array}$ & $\begin{array}{l}\text { CRS underwent } \\
\text { allergen } \\
\text { sensitization } \\
\text { work-up by skin } \\
\text { prick test with } \\
\text { common } \\
\text { inhalant } \\
\text { allergens and } \\
\text { total IgE } \\
\text { measurement. }\end{array}$ & $\begin{array}{l}\text { Prevalence of } \\
\text { sensitization to } \\
\text { aeroallergens in } \\
\text { children with } \\
\text { CRS is } \\
\text { comparable with } \\
\text { that of the } \\
\text { general pediatric } \\
\text { population. }\end{array}$ & No (Level IV) \\
\hline $\begin{array}{l}\text { linking allergy } \\
\text { to outcome of } \\
\text { CRS } \\
\text { treatments in } \\
\text { children }\end{array}$ & $\begin{array}{l}\text { linking allergy } \\
\text { to outcome of } \\
\text { CRS } \\
\text { treatments in } \\
\text { children }\end{array}$ & $\begin{array}{l}\text { linking allergy } \\
\text { to outcome of } \\
\text { CRS } \\
\text { treatments in } \\
\text { children }\end{array}$ & $\begin{array}{l}\text { linking allergy } \\
\text { to outcome of } \\
\text { CRS } \\
\text { treatments in } \\
\text { children }\end{array}$ & $\begin{array}{l}\text { linking allergy } \\
\text { to outcome of } \\
\text { CRS } \\
\text { treatments in } \\
\text { children }\end{array}$ & $\begin{array}{l}\text { linking allergy } \\
\text { to outcome of } \\
\text { CRS } \\
\text { treatments in } \\
\text { children }\end{array}$ \\
\hline $\begin{array}{l}\text { Nathan et al. } \\
2004(64)\end{array}$ & $\begin{array}{l}\text { Prospective } \\
\text { observational } \\
\text { study }\end{array}$ & $\begin{array}{l}\mathrm{N}=114 \mathrm{RA} \text { and } \\
\mathrm{CRS} \text { (children } \\
\text { and adult) }\end{array}$ & $\begin{array}{l}\text { Patients were } \\
\text { surveyed for } \\
\text { global symptoms } \\
\text { and specific } \\
\text { symptoms } \\
\text { related to the } \\
\text { nose, sinuses, } \\
\text { eyes, and chest } \\
\text { with the SOQ }\end{array}$ & $\begin{array}{l}\text { Immunotherapy } \\
\text { is an effective } \\
\text { treatment for } \\
\text { patients with } \\
\text { sinus disease and } \\
\text { allergic rhinitis. }\end{array}$ & Yes (Level II) \\
\hline$\underset{(65)}{\text { Kim et al. } 2005}$ & $\begin{array}{l}\text { Retrospective } \\
\text { observational } \\
\text { study. }\end{array}$ & $\begin{array}{l}\mathrm{N}=97 \text { patients } \\
\text { (age range: } \\
5-15 \text { years) }\end{array}$ & $\begin{array}{l}\text { Retrospective } \\
\text { analysis of } \\
\text { long-term } \\
\text { success rates of } \\
\text { ESS respect to } \\
\text { several } \\
\text { predisposing } \\
\text { factors. }\end{array}$ & $\begin{array}{l}\text { Multivariate } \\
\text { logistic } \\
\text { regression } \\
\text { analysis allergy } \\
\text { was not } \\
\text { correlated to } \\
\text { poor outcomes } \\
\text { after pediatric } \\
\text { ESS }\end{array}$ & No (Level IV) \\
\hline
\end{tabular}




\begin{tabular}{|c|c|c|c|c|c|}
\hline $\begin{array}{l}\text { Clinical } \\
\text { evidence } \\
\text { linking allergy } \\
\text { to risk of CRS } \\
\text { in children }\end{array}$ & $\begin{array}{l}\text { Clinical } \\
\text { evidence } \\
\text { linking allergy } \\
\text { to risk of CRS } \\
\text { in children }\end{array}$ & $\begin{array}{l}\text { Clinical } \\
\text { evidence } \\
\text { linking allergy } \\
\text { to risk of CRS } \\
\text { in children }\end{array}$ & $\begin{array}{l}\text { Clinical } \\
\text { evidence } \\
\text { linking allergy } \\
\text { to risk of CRS } \\
\text { in children }\end{array}$ & $\begin{array}{l}\text { Clinical } \\
\text { evidence } \\
\text { linking allergy } \\
\text { to risk of CRS } \\
\text { in children }\end{array}$ & $\begin{array}{l}\text { Clinical } \\
\text { evidence } \\
\text { linking allergy } \\
\text { to risk of CRS } \\
\text { in children }\end{array}$ \\
\hline $\begin{array}{l}\text { El Sharkawy } \\
2012(66)\end{array}$ & $\begin{array}{l}\text { Prospective } \\
\text { observational } \\
\text { study. }\end{array}$ & $\begin{array}{l}\mathrm{N}=87 \text { children } \\
\text { (45 with nasal } \\
\text { allergy) } \\
\text { (age[?]14) }\end{array}$ & $\begin{array}{l}\text { To assess } \\
\text { predictive factors } \\
\text { of outcome after } \\
\text { ESS. }\end{array}$ & $\begin{array}{l}\text { The success rate } \\
\text { in CRS with } \\
\text { nasal allergy was } \\
87.5 \% \text {, and in } \\
\text { CRS without } \\
\text { nasal allergy was } \\
85.7 \% \text {. }\end{array}$ & No (Level II) \\
\hline $\begin{array}{l}\text { Lee et al. } 2009 \\
(68)\end{array}$ & $\begin{array}{l}\text { Retrospective } \\
\text { analysis }\end{array}$ & $\begin{array}{l}\mathrm{N}=53 \text { children } \\
\text { who underwent } \\
\text { FESS } \\
(\text { age }<18 \mathrm{yr})\end{array}$ & $\begin{array}{l}\text { To investigate } \\
\text { factors leading } \\
\text { to protracted } \\
\text { nasal discharge } \\
\text { after pediatric } \\
\text { endoscopic sinus } \\
\text { surgery. }\end{array}$ & $\begin{array}{l}\text { Blood eosinophil } \\
\text { count did not } \\
\text { differ } \\
\text { significantly } \\
\text { between the } \\
\text { "protracted" and } \\
\text { the "resolved" } \\
\text { groups. On the } \\
\text { other hand, } \\
\text { history of } \\
\text { allergic rhinitis } \\
\text { was more } \\
\text { frequently } \\
\text { observed in the } \\
\text { "protracted" } \\
\text { group. }\end{array}$ & Yes (Level IV) \\
\hline $\begin{array}{l}\text { Wu et al. } 2019 \\
(69)\end{array}$ & $\begin{array}{l}\text { Retrospective } \\
\text { analysis }\end{array}$ & $\begin{array}{l}\mathrm{N}=188 \text { children } \\
\text { ESS for CRS. }\end{array}$ & $\begin{array}{l}\text { To evaluate } \\
\text { prognostic } \\
\text { factors related to } \\
\text { revision surgery } \\
\text { after ESS. }\end{array}$ & $\begin{array}{l}\text { Patients with } \\
\text { positive } \\
\text { aeroallergen } \\
\text { tests had higher } \\
\text { rates of CRS } \\
\text { recurrence after } \\
\text { ESS and } \\
\text { required revision } \\
\text { surgery. }\end{array}$ & Yes (Level IV) \\
\hline
\end{tabular}

CRS: chronic rhinosinusitis; AR: allergic rhinitis; PAR: perennial allergic rhinitis; SAR: seasonal allergic rhinitis; SOQ: Sinusitis Outcome Questionnaire; ESS: endoscopic sinus surgery; FESS: functional endoscopic sinus surgery.

Figure 1. Flow chart of articles selection. 


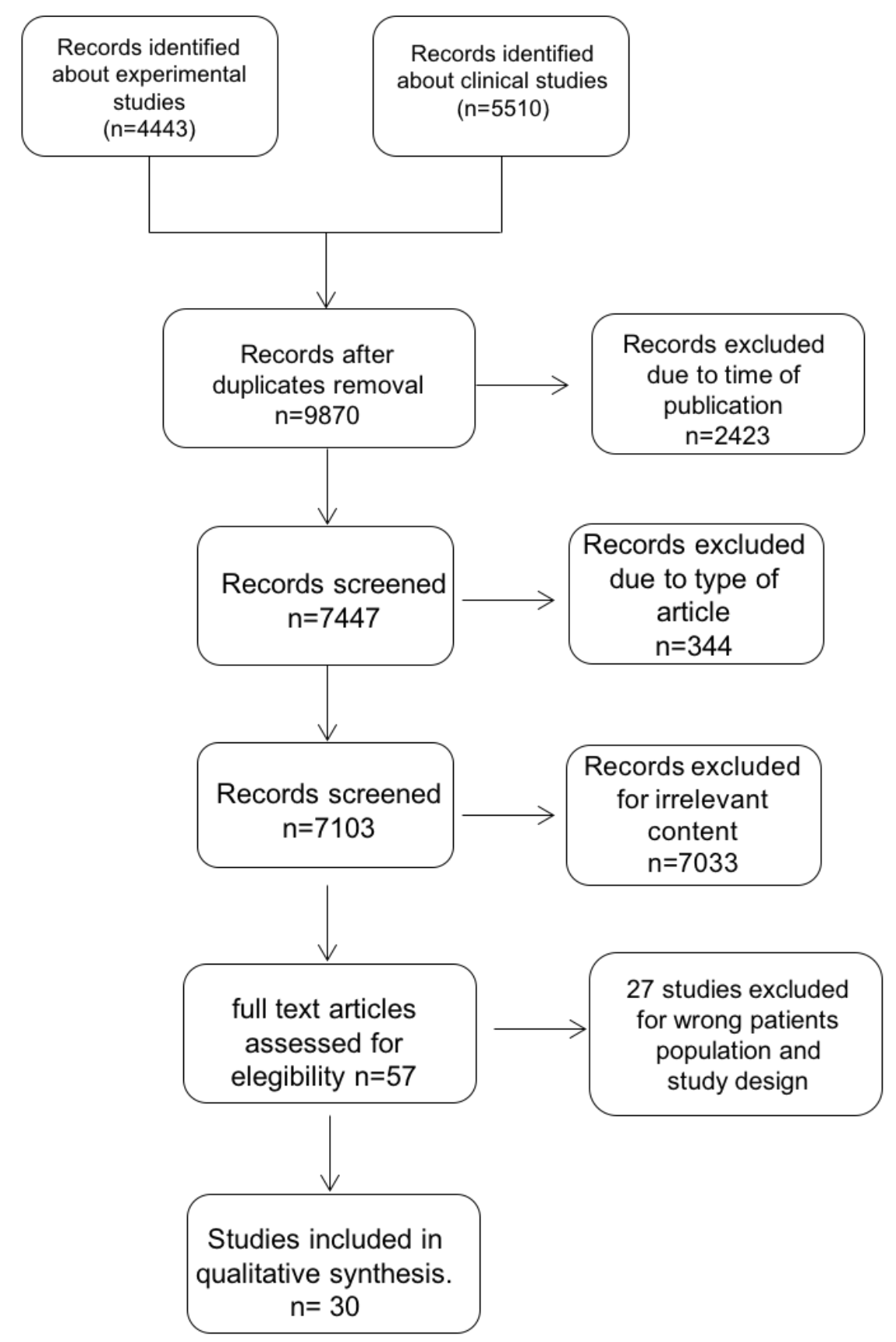

Figure 2: Practical algorithm based on different phenotypes of rhinosinusitis in children. 


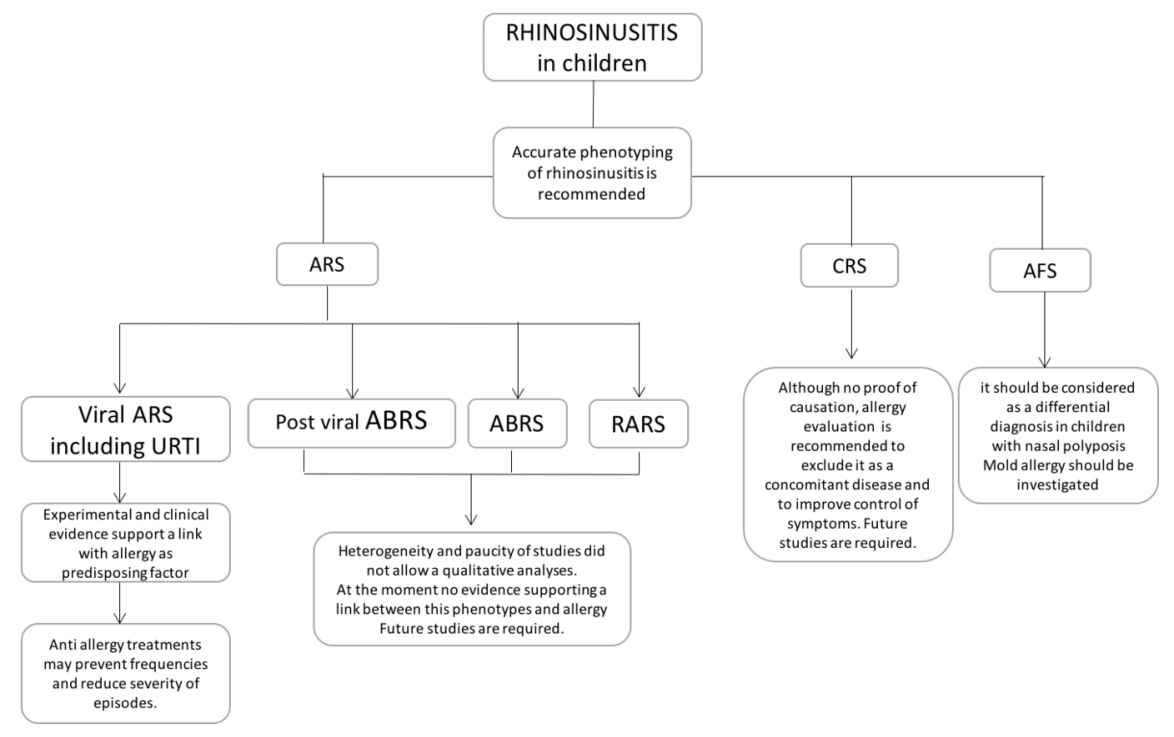




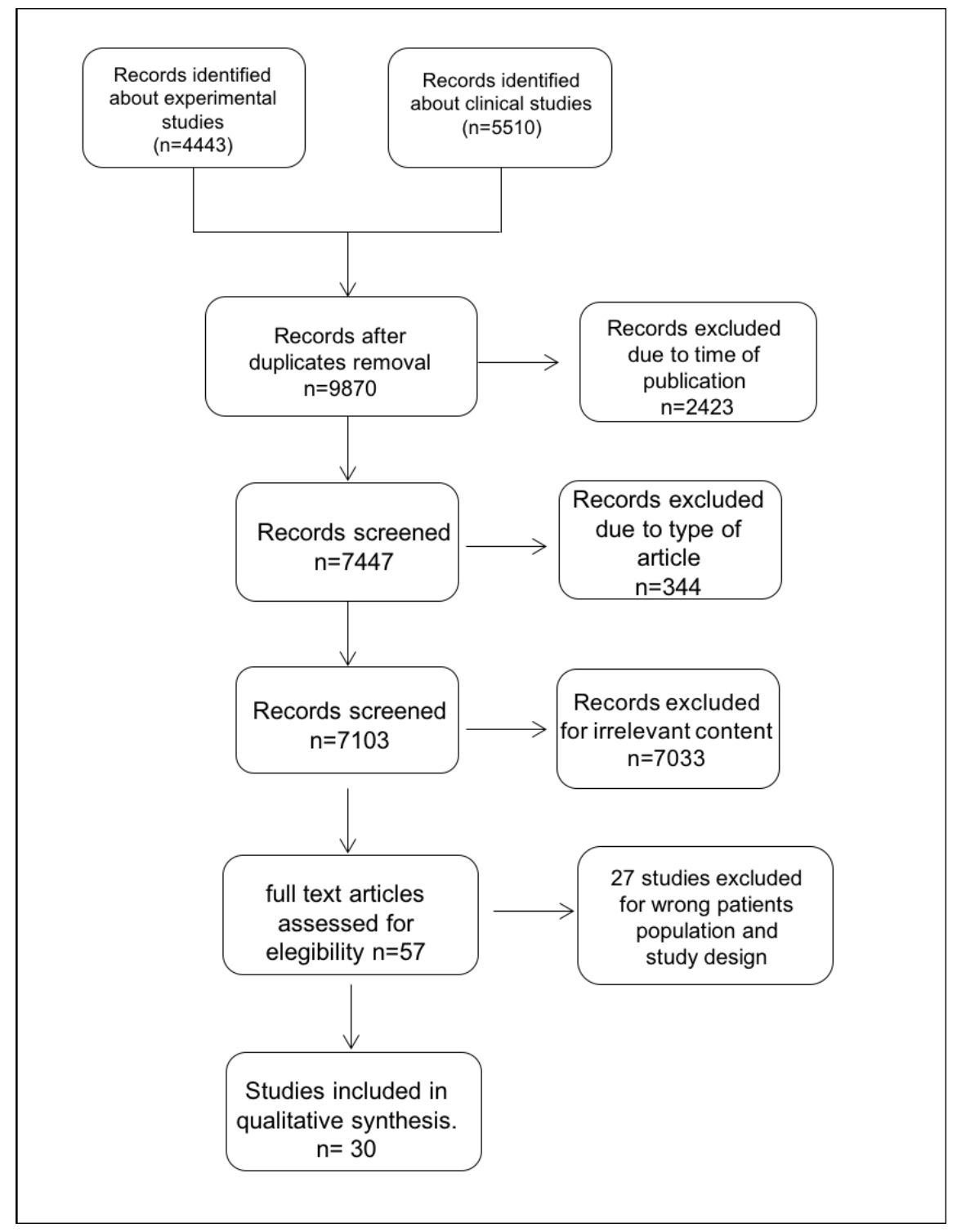




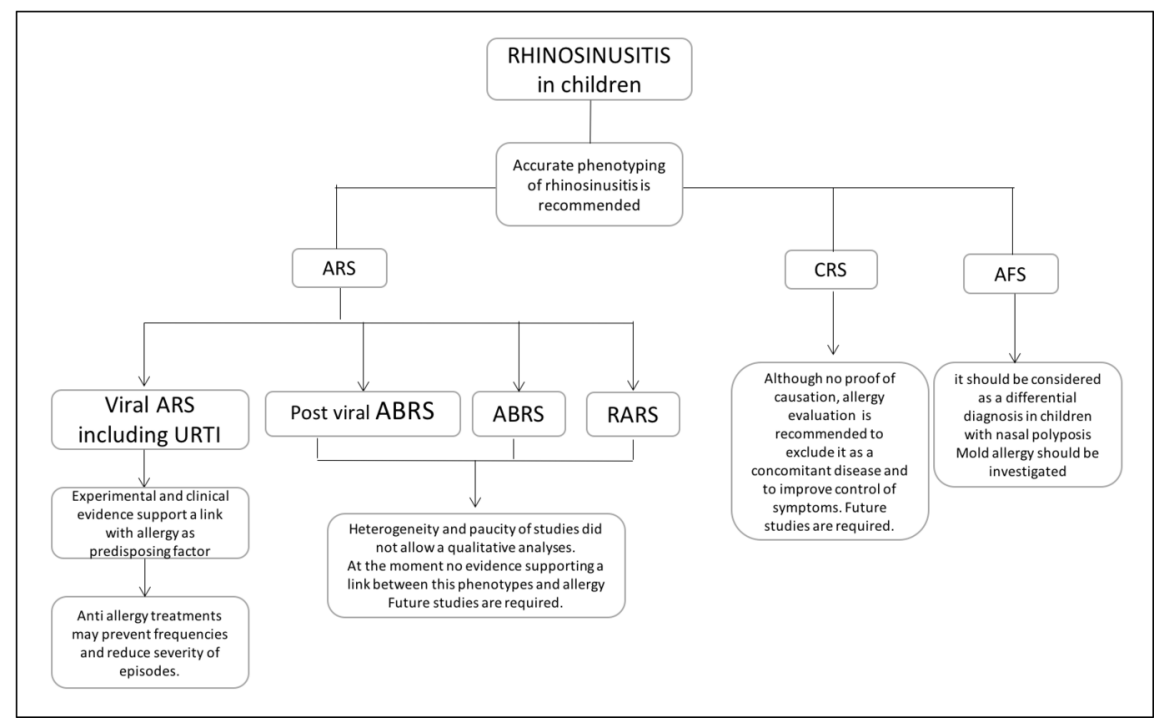

